\title{
Chapter 2 \\ Role of Nucleopolyhedroviruses (NPVs) in the Management of Lepidopteran Pests in Asia
}

\author{
G.V. Ranga Rao, Ch. Sridhar Kumar, K. Sireesha, and P. Lava Kumar
}

\subsection{Introduction}

The use of synthetic insecticides has been the major approach in modern agriculture for controlling insect pests on different crops in most of the developing countries. Chemical control is one of the effective and quicker methods in reducing pest population, where farmer obtains spectacular results within a short period. However, overreliance and indiscriminate unscientific use of pesticides for longer periods resulted in a series of problems, mainly risk of environmental contamination, loss of biodiversity, development of insecticide-resistant pest populations, resurgence, outbreaks of the secondary pests, increase in inputs on chemicals and toxicological hazards due to accumulation of pesticide residues in the food chain, etc., ultimately contributing not only to inefficient insect control but also environmental and health hazards (Armes et al. 1992; Kranthi et al. 2002). Therefore, there is an urgent need to rationalize the use of chemical pesticides for the management of insect pests. In recent years, the growing public concern over potential health hazards of synthetic pesticides has led to the exploration of alternative pest management options, such as adoption of integrated pest management (IPM). IPM combines cultural, biological, and chemical measures in the most effective, environmentally sound, and socially acceptable way of managing pests, diseases, and weeds. IPM aims at suppressing the pest population by combining available methods in a harmonious way with emphasis on farm health and net returns. In an attempt to overcome the present crisis and to find alternatives to synthetic

G.V.R. Rao $(\bowtie) \cdot$ Ch.S. Kumar • K. Sireesha

International Crops Research Institute for the Semi-Arid Tropics (ICRISAT), Patancheru,

Telangana 502324, India

e-mail: g.rangarao@cgiar.org

P.L. Kumar

International Institute of Tropical Agriculture (IITA), Ibadan, Oyo State, PMB 5320, Nigeria

e-mail: L.kumar@cgiar.org 
insecticides, the application of "bio-pesticides" as an eco-friendly measure for pest suppression has come up as one of the effective tools in IPM approach.

Bio-pesticides are developed from natural plant or animal origin, which can intervene in the life cycle of insect pests in such a way that the crop damage is minimized. The biological agents employed for this purpose include parasites, predators, and disease-causing fungi, bacteria, nematodes, and viruses, which are the natural enemies/pathogens of pests. More than three thousand microorganisms, comprising viruses, bacteria, fungi, protozoa, and nematodes, have been reported as insect pathogens. Of these, microbial pathogens gained significance for use as bio-pesticides primarily due to ease in production, application, wider adoptability, persistence, economic feasibility, and environmental compatibility. Many species of insect pathogenic microorganisms have been exploited as bio-pesticides, and some species have been developed into commercial formulations that are being used in many countries. Though farmers in Asia are aware of the importance of IPM and its impact on health and environment, the adoption level was not up to the expected levels. However, recent estimates are quite encouraging with reduction in chemical use to $\$ 25.3$ billion in 2010 compared to $\$ 26.7$ billion in 2005 . On the other hand, interestingly, the bio-pesticides market is growing rapidly from $\$ 672$ million in 2005 to over $\$ 1$ billion in 2010 (Anon 2009). Several viruses belonging to 18 different families are known to infect invertebrates and insects (Fauquet et al. 2004). However, bio-pesticide development is concerned almost exclusively with members of one family, the Baculoviridae, because of their common occurrence in most important insect pests primarily in the order of Lepidoptera and their action as natural regulators of pest populations (Weiser 1987; Gelernter and Federici 1990; Caballero et al. 1992; Blissard et al. 2000). The potential of baculoviruses to be employed as insecticides is known since more than 75 years ago (Benz 1986). To date, over 30 different baculoviruses are used to control several insect pests in agriculture and forestry (Moscardi 1999). The use of baculovirus as insecticides is based on a set of useful properties, such as pathogenicity, specificity, narrow host range, environmental persistence, suitability to add to other bio-agents with synergism, and ability to induce epizootics. There are several advantages of using insect viruses in pest management over traditional synthetic chemical insecticides: these are highly host specific and are known to be completely safe to humans, animals, and non-target beneficial insects such as bees, predatory insects, and parasitoids (Groner 1986; Monobrullah and Nagata 1999; Nakai et al. 2003; Ashour et al. 2007); lack of toxic residues allowing growers to treat their crops even shortly before harvest, with low probability to develop stable resistance (Monobrullah 2003). These are highly compatible with other methods of pest control and are well suited for use in IPM programs. Another important reason for the interest in baculoviruses as potential insect control agents is that they are relatively easy to visualize and monitor using a light microscope. In vivo and in vitro tests with several vertebrate, invertebrate, and plant species have not demonstrated any pathogenic, toxic, carcinogenic, or teratogenetic effects after exposure to these viruses (Ignoffo and Rafajko 1972; Ignoffo 1973; Banowetz et al. 1976; Lautenschlager et al. 1977; Roder and Punter 1977; Huber and Krieg 
1978). Baculoviruses are stable and can be stored as aqueous suspensions or dried powders for long periods without any loss of activity (David and Gardiner 1967a). They are resistant to many chemicals and persist in the soil for many years (David and Gardiner 1967b), and their activity is not altered significantly by relative humidity (David et al. 1971), precipitation (David and Gardiner 1966), or prolonged exposure to normal field temperatures (Yendol and Hamlen 1973). They can be used concurrently with most chemical insecticides and permit the reduction of the number of applications needed to keep the insect plague under control in crops, thus contributing to the reduction of the costs of protection. Finally, its use in replacement of synthetic insecticides helps to reduce the overall levels of chemical pollution (Falcon 1971; Hunter et al. 1975; Jacques and Long 1978). Baculoviruses differ significantly from chemical insecticides in that they are components of nature. Large quantities of virus are released into the environment during natural epizootics, which are common, widespread, and often important in regulating insect population levels (Injac 1973; Federici 1978). There is evidence that the amount of virus which is artificially placed into the environment as bio-pesticide is minimal compared with the amount produced during such epizootics (Thomas 1975).

\subsection{Classification of Baculoviruses}

Baculoviruses are occluded, double-stranded DNA (dsDNA) viruses and characterized by the presence of occlusion or inclusion bodies (OBs). The nature and significance of these OBs remained a mystery for a long time until the electron microscope (EM) was available that the virus particle could be isolated and identified as the infectious viral agent. Based on the size, shape, and occluded virion phenotype, the baculoviruses are classified into two genera, nucleopolyhedroviruses (NPVs) and granuloviruses (GVs) (Rohrmann 1999; Winstanley and O'Reilly 1999; Blissard et al. 2000; Fauquet et al. 2004). The EM observation of NPVs reveals polyhedral to irregular shaped OBs with size $0.15-15 \mu \mathrm{m}$ in diameter (Figs. 2.1 and 2.2) composed of matrix protein (30-40\% of total viral protein) called polyhedrin, which crystallizes around many enveloped nucleocapsids (Hooft van Iddekinge et al. 1983). Different NPVs are characterized by their occluded virions being present either as single (SNPV) or multiple (MNPV) nucleocapsids within the envelope (Figs. 2.1 and 2.3). Both SNPVs and MNPVs may contain 20200 virions depending upon species (Rohrmann 1999). The GVs have small OBs $(0.25-0.5 \mu \mathrm{m}$ in cross section), are ellipsoidal in shape, and normally contain a single nucleocapsid, which is enveloped and is composed of a major matrix protein called granulin (Funk et al. 1997; Winstanley and O'Reilly 1999). NPVs are found mostly in the order Lepidoptera, Hymenoptera (31 species), Diptera (27 species), and Coleoptera (5 species) as well as from the crustacean class Decapoda (shrimp), whereas GVs are only found within the order Lepidoptera (Federici 1997; Blissard et al. 2000). Virions consist of one or more nucleocapsids embedded in a 


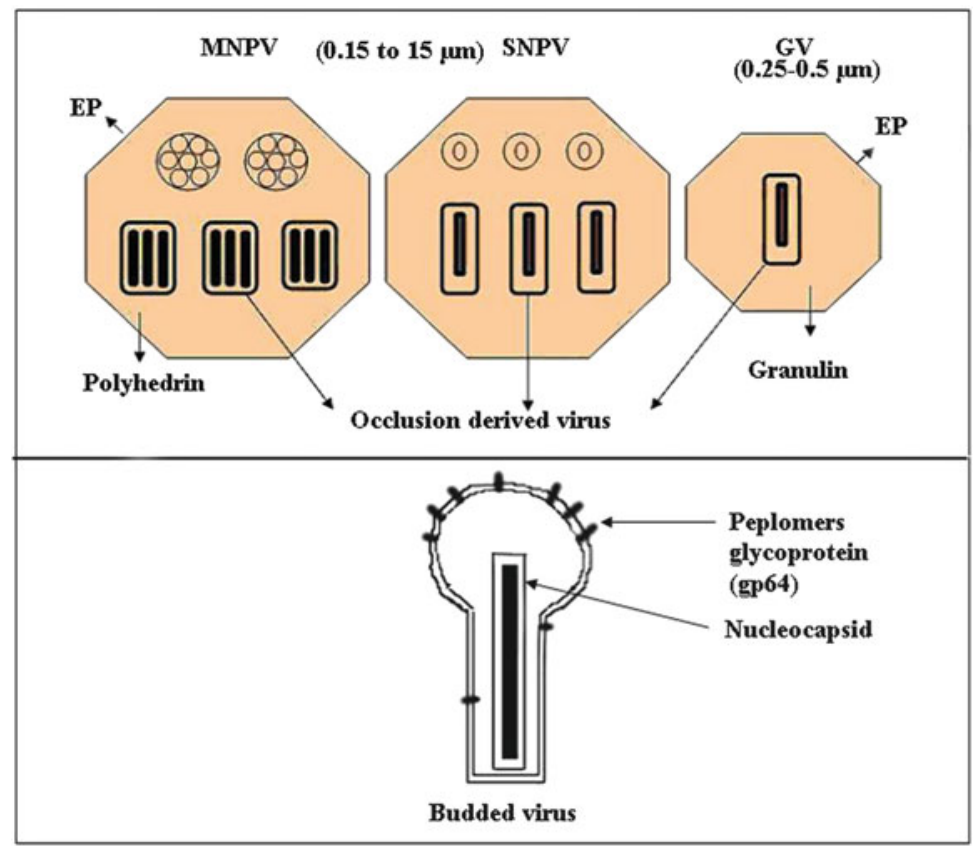

Fig. 2.1 Morphological characteristics of nucleopolyhedroviruses (NPVs) and granuloviruses (GVs)

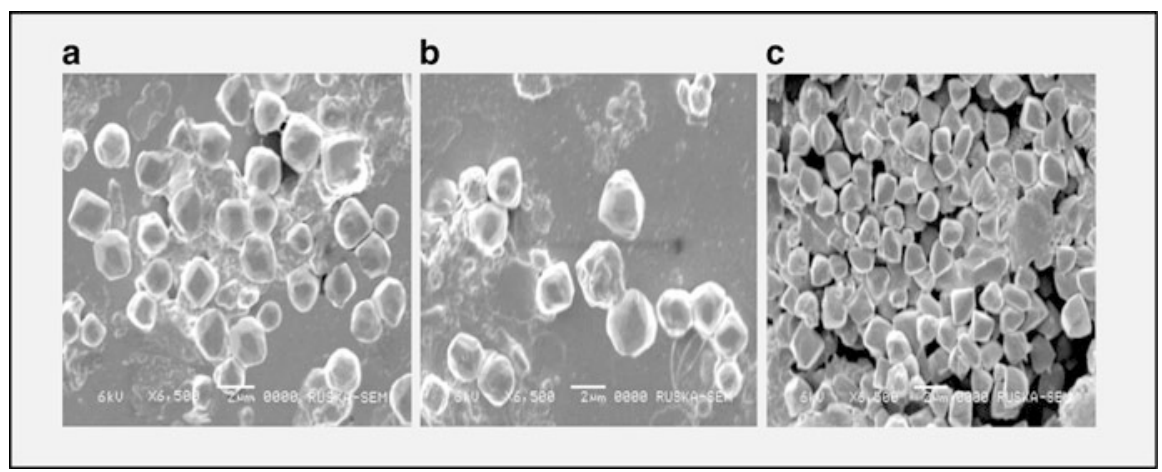

Fig. 2.2 Scanning electron micrograph of POBs: scanning electron micrograph (SEM) images of occlusion bodies (OBs) of baculoviruses. The purified aqueous $\mathrm{OBs}$ of baculoviruses isolated from (a) H. armigera, (b) S. litura, and (c) A. albistriga were dehydrated, mounted over the stubs, applied with a thin layer of gold metal over the sample using sputter coater, and then scanned under EM. Magnification $=6,500 \times$

membranous envelope. Two morphologically distinct but genetically identical viral forms are produced during postinfection: (a) budded virus particles (BV) which serve for the transmission of the virus to other tissues of the infected pest and 


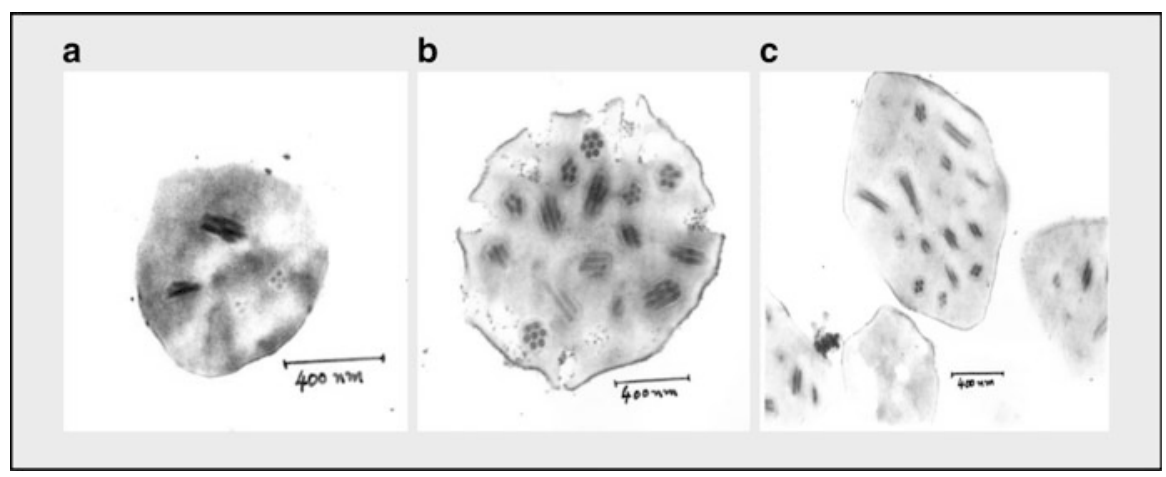

Fig. 2.3 Transmission electron micrographs of the cross section of poly-occlusion bodies (POBs): Pellets of purified OBs of baculoviruses isolated from (a) H. armigera, (b) S. litura, and (c) A. albistriga were subjected to ultrathin sections, mounted on copper grids, and stained with saturated aqueous uranyl acetate and counterstained with $4 \%$ lead citrate and observed under TEM. Magnification $=25,000 \times$

(b) OBs which are responsible for the survival of the virus and spread of the disease. The OB (polyhedra) of NPV contains many occlusion-derived virions (ODV) surrounded by a matrix composed of mainly polyhedrin, a major structural protein (Braunagel et al. 2003). Polyhedrin is produced in large quantities (around $30 \%$ of total protein mass at the time of host death). Polyhedra are relatively stable and under favorable conditions virions can survive in the environment for more than 20 years. Under magnification of around 1,000 $\times$, polyhedra resemble clear, irregular crystals of salt; so they are big enough to be seen in a light microscope. Some common symptoms of the virus attack are sluggishness, discoloration of skin, wet or extremely moist droppings, and regurgitation of fluids (a sign of stress).

The size and shape of occlusion bodies in NPVs varies considerably not only between the polyhedral occlusion bodies (POBs) from different insects but often also within the same species. For example, majority of the POBs of Helicoverpa armigera NPV are spherical, while some of them are irregular in shape and the size ranges from 0.6 to $2.3 \mu \mathrm{m}$, averaging to $1.35 \mu \mathrm{m}$ (Fig. 2.2). The diameter of polyhedra ranges about $0.5-1.5 \mu \mathrm{m}$, depending on the insect species (Fig. 2.3). The differentiation in the cross section of typical baculovirus (NPV and GV) occlusion bodies (OBs) is clearly represented in Fig. 2.1. In the boundary of OB, the protein envelope (PE) appears as an electron-dense layer made up of PE protein or envelope protein and shown to be very sensitive to alkaline proteases (Russell and Rohrmann 1990; Van Lent et al. 1990). The distance between envelope and crystalline matrix (polyhedrin or granulin) is not uniform around the occlusion body. The fine structure of occlusion body reveals crystalline lattice of the occlusion body protein molecules, which are arranged in cubic system. Although there is no true membrane covering the $\mathrm{OB}$, difficulties in staining $\mathrm{OB}$, the retention of their shape, and the presence of a membrane-like coat following chemical and physical treatment indicate that the exterior portion of $\mathrm{OB}$ is different from the interior portion. On the whole, they are very stable and can persist indefinitely in the 
environment (Bergold 1982). The infectious, rod-shaped virions are randomly occluded in OBs without any apparent disruption of the lattice; an 8-nm layer separates virion from the protein matrix. The size of the virions is with dimensions in the range from 4.0 to $140 \times 250$ to $400 \mathrm{~nm}$. Alkaline-liberated virions readily lose their envelopes to reveal nucleocapsids each made up of a capsid surrounding a DNA core. The capsid, in turn, consists of protein subunits arranged along its long axis. The virions contain large circular, covalently closed, dsDNA genome with size in range of 80-180 kbp packed in the nucleocapsid (Blissard and Rohrmann 1990; Volkman et al. 1995).

\subsection{Examples of Some Commercial Baculovirus-Based Products Registered in Different Countries for Pest Management}

Over 20 species of baculoviruses have been developed or registered as commercially available insecticides, and over 30 different products have been registered as commercial insecticides based upon NPV or GV. Autographa californica and Anagrapha falcifera NPVs were registered in various countries and have relatively broad host spectrum and potentially can be used on a variety of crops infested with pests including Spodoptera and Helicoverpa. GV is the active component of a number of bio-pesticides used for protection of apple and pear orchards against the codling moth, Cydia pomonella. Some of the trademarks of GV-based products are the following: Granusal ${ }^{\mathrm{TM}}$ in Germany, Carpovirusine ${ }^{\mathrm{TM}}$ in France, Madex ${ }^{\mathrm{TM}}$ and Granupom $^{\mathrm{TM}}$ in Switzerland, and Virin-CyAP in Russia. Annually, up to 250,000 ha of orchards have been protected with Madex ${ }^{\mathrm{TM}}$ in different European countries (Vincent et al. 2007). Another GV infecting Erinnyis ello (cassava hornworm) was found to be very efficient in protection of cassava plantations (Bellotti 1999). This GV has been used for spraying cassava crops in South American countries. Two commercial preparations based on Spodoptera NPV have been available. These are SPOD-X ${ }^{\mathrm{TM}}$ containing Spodoptera exigua NPV to control insects on vegetable crops and Spodopterin ${ }^{\mathrm{TM}}$ containing Spodoptera littoralis NPV which is used to protect cotton, corn, and tomatoes (Szewczyk et al. 2006). In China, twelve baculoviruses have been authorized as commercial insecticides (Sun and Peng 2007), including H. armigera NPV (the most widely used virus in China for cotton, pepper, and tobacco protection), Spodoptera litura NPV (vegetables), S. exigua NPV (vegetables), Buzura suppressaria NPV (tea), Pieris rapae GV, and Plutella xylostella GV (vegetables). China is the largest user of baculoviruses worldwide, with maximum number of viruses being registered for insect control. The well-known success of employing baculovirus as a bio-pesticide is the case of Anticarsia gemmatalis nucleopolyhedrovirus (AgMNPV) used to control the velvetbean caterpillar in soybean (Moscardi 1999). This program was implemented in Brazil in the early 1980s and came up to over 2,000,000 ha of 
soybean treated annually with the virus. The use of AgMNPV in Brazil brought about many economical, ecological, and social benefits. The protection of soybean fields in Brazil has proven that baculoviral control agents can be effectively produced on a large scale and they may be an alternative to broad-spectrum chemical insecticides. The forests of temperate regions are very often attacked and defoliated by larvae of Lepidoptera (the most common pest species are Lymantria dispar, Lymantria monacha, Orgiya pseudotsugata, and Panolis flammea) and some hymenopteran species (mainly Neodiprion sertifer and Diprion pini). L. dispar MNPV formulations marketed under trade names Gypchek, Disparivirus, and Virin-ENSH and $O$. pseudotsugata MNPV under trade names BioControl-1 and Virtuss (Reardon et al. 1996) are sometimes used for forest protection. Forest ecosystems tend to be more stable than agricultural systems, allowing for natural or applied baculoviruses to remain in the environment for long periods of time increasing the chance of natural epizootics.

\subsection{Isolation and Characterization}

Among the baculoviruses, NPVs attracted more attention of plant protection scientists who were looking for an alternative to pesticides because they cause a highly infectious disease that kills the pest within 5-7 days. These viruses attack some of the most important Lepidopteran crop pests including the species of Helicoverpa, Spodoptera, and Amsacta. Some of the related GV species are also highly infectious, e.g., Cydia pomonella (apple codling moth) GV and P. xylostella (diamond back moth) GV. However, not all GVs are as fast acting as NPV because morphologically they had single envelope with single nucleocapsid per occlusion body (Winstanley and O'Reilly 1999) (Fig. 2.1). In general, the host range of most NPV is restricted to one or a few species of the genus or family of the host where they were originally isolated. However, it also addresses an important commercial drawback, restricting the use of these products to specific pest or closely related pest complexes, such as Helicoverpa species (Chakraborthy et al. 1999). Some of the few exceptions having a broader host range are (1) A. californica MNPV infecting more than 30 species from about 10 insect families, all within the order Lepidoptera; (2) A. falcifera NPV infecting more than 31 species of Lepidoptera from ten insect families; and (3) Mamestra brassicae MNPV which was found to infect 32 out of 66 tested Lepidopteran species from four different families (Groner 1986; Doyle et al. 1990; Hostetter and Puttler 1991). In contrast to NPV, the host range of GV appears to be even narrower and mostly restricted to a single species. In India, about 35 insect viruses have been recorded from the baculovirus group, the most important being the NPVs of H. armigera, S. litura, Spilosoma obliqua (Walker), Achaea janata (L.), and Amsacta albistriga (Walker) and the GVs of A. janata, S. litura, H. armigera, and Chilo spp. (Pawar and Thombre 1992). 


\subsubsection{Morphological Characterization}

During natural epizootic conditions, baculoviruses were isolated from larvae of H. armigera (Hübner) (Lepidoptera: Noctuidae), S. litura (Fabricius) (Lepidoptera: Noctuidae), and A. albistriga (Walker) (Lepidoptera: Arctiidae) at ICRISAT farms, and the viruses isolated from these insect pests were characterized as MNPVs by conducting morphological and biological studies (Sridhar Kumar et al. 2011). The diseased larvae showed the typical baculovirus infection symptoms. The infected larvae showed pale swollen bodies and are moribund. The larvae of $H$. armigera and $A$. albistriga crawled to the top of the twigs (negative geotropism) on which they fed (Fig. 2.4). But the larva of S. litura did not show this feature due to its soil inhabiting nature and nocturnal habitat. The initial signs of baculoviral infection are gradual changes in the color and luster of the integument. Infection of the epidermis caused the host to appear soft and in some larvae the cuticle was ruptured and discharging of body fluid onto plant parts was observed. Earlier, these symptoms were also reported by others (Aizawa 1963; Tanada and Kaya 1993; Federici 1997). Observation of discharged body fluid under phase contrast microscope revealed that it consists of OBs (Fig. 2.5). Electron microscopic studies of OBs indicated that the viruses isolated were NPVs rather than GVs. Under scanning electron microscope, the OBs appeared as irregular shaped structures with sizes ranging from 0.5 to $2.5 \mu \mathrm{m}$ ( $\mathrm{HaNPV}$ ), 0.9 to $2.92 \mu \mathrm{m}$ (SlNPV), and 1.0 to $2.0 \mu \mathrm{m}$ (AmalNPV) in diameter (Fig. 2.2). Transmission electron microscopic (TEM) studies on cross sections of purified POBs of these viruses showed that each occlusion body contains 2-7 (multiple) nucleocapsids packaged within a single viral envelope. The nucleocapsids are elongated with parallel sides and two straight ends, measuring $277.7 \times 41.6 \mathrm{~nm}(H a \mathrm{NPV}), 285.7 \times 34.2 \mathrm{~nm}($ SlNPV$)$, and $228.5 \times 22.8 \mathrm{~nm}$ (AmalNPV) (Fig. 2.3). Before characterization of any baculovirus from an insect host, initially, it is necessary to conduct electron microscopic study (SEM and TEM) to determine whether it is NPV or GV or SNPV or MNPV. Similarly, Tuan et al. (1999) reported that the occlusion bodies of HaNPV and SlNPV isolated in Taiwan were irregular shaped with sizes ranging from $0.79 \pm 0.22 \mu \mathrm{m}$ ( $\mathrm{HaNPV}$ )
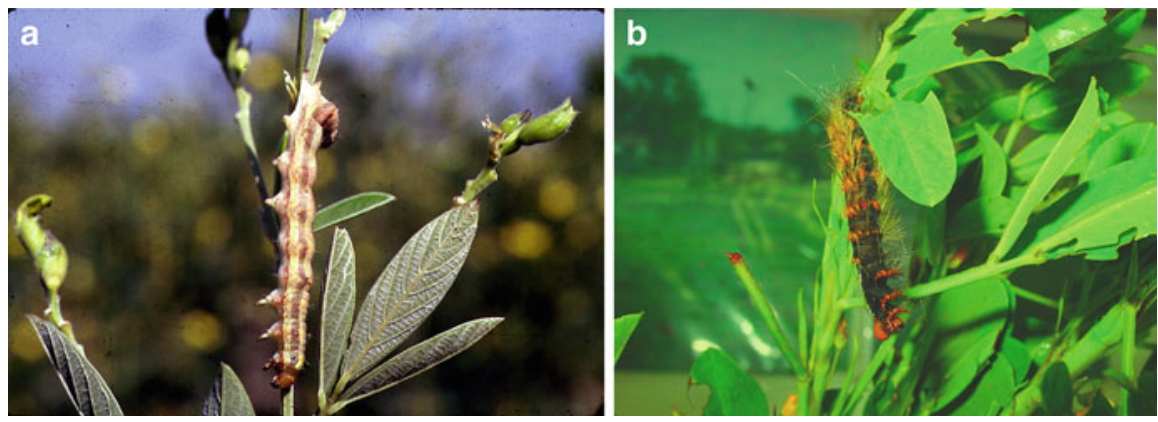

Fig. 2.4 NPV-infected larvae of $H$. armigera and $A$. albistriga: NPV-infected larvae of $H$. armigera on pigeon pea (a) and A. albistriga on groundnut (b) 


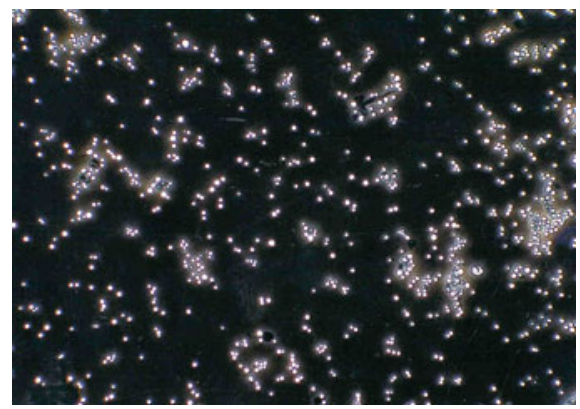

Fig. 2.5 Enumeration of poly-occlusion bodies (POBs) under phase-contrast microscope: POBs of NPVs were purified by differential centrifugation and enumerated under phase-contrast microscope at $1,000 \times$ magnification

and $1.61 \pm 0.32 \mu \mathrm{m}($ SlNPV); both viruses were MNPVs and the nucleocapsids were bacilliform to cylindrical tubular-shaped structures with dimensions of $319.80 \pm 7.80 \times 44.45 \pm 4.54 \mathrm{~nm}(\mathrm{HaNPV})$ and $332.26 \pm 13.55 \times 47.16 \pm 1.42 \mathrm{~nm}$ (SlNPV). In another study, the polyhedra of the L. dispar MNPV-NM isolate were irregularly shaped with an average diameter of $1.62 \pm 0.33 \mu \mathrm{m}$. TEM revealed that LdMNPV-NM had bundles of virions in the nucleocapsid, which belonged to MNPV (Shim et al. 2003). Wolff et al. (2002) reported the morphology of an MNPV isolated from Lonomia obliqua (Lepidoptera: Saturniidae) with size ranging from 1 to $1.4 \mu \mathrm{m}$ and nucleocapsid dimensions of $270 \times 36 \mathrm{~nm}$. Ma et al. (2006) observed the occlusion bodies in the midgut tissues of the tea looper (Ectropis obliqua) under TEM, the micrograph showed that the EcobSNPVs were irregular shaped with size ranging from 0.7 to $1.7 \mu \mathrm{m}$ in diameter, and multiple rod-shaped virions measuring about $250 \times 40 \mathrm{~nm}$ were embedded in each $\mathrm{OB}$ with a single nucleocapsid packaged within the envelope of the virion.

\subsubsection{Biological Characterization}

Biological assessment studies of the MNPVs isolated at ICRISAT farms from $H$. armigera, S. litura, and A. albistriga indicated (Tables 2.1 and 2.2) that they are highly virulent strains and have good potential for use as bio-control agents against these important pests (Sridhar Kumar et al. 2011). The efficacy of HaNPV isolates collected from six geographical locations of India was tested by conducting bioassay experiments at ICRISAT with the second and third instar larvae of $H$. armigera, and it was found that ICRISAT $H a \mathrm{NPV}$ was superior amongst the isolates tested (Sireesha 2006). Similar differences in virulence among NPV isolates have been established in previous studies conducted by Shapiro and Ignoffo (1970) on the variations in virulence of 34 isolates of $\mathrm{HaNPV}$. A 56-fold difference in the activity of the isolates was recorded, and it was opined that the difference in activity must be due to some characteristics of the occlusion body and/or its 
occluded virions. They also did not exclude the possibility that some other factors such as solubility of occlusions and availability of occluded virions may account for the differences observed. Abul-Nasr and Elnagar (1980) reported the differential biological activity of two Spodoptera littoralis isolates both at laboratory- and fieldlevel studies. Hughes et al. (1983) compared the time mortality response of Heliothis zea to 14 isolates of HzNPV and identified six activity classes. Shapiro et al. (1984) tested $19 \mathrm{NPV}$ isolates of $L$. dispar and reported nearly 1,000-fold difference in activity. Rabindra (1992) demonstrated the tremendous variation in virulence among the three $\mathrm{HaNPV}$ isolates and recorded the lowest $\mathrm{LC}_{50}$ value of $3.467 \times 10^{4} \mathrm{POBs} / \mathrm{ml}$ for the $\mathrm{HaNPV}$ isolate from Nilgiris. Somasekhar et al. (1993) on characterizing five Indian isolates of $\mathrm{HaNPV}$ found that the most virulent isolate was that from Ooty in Tamil Nadu, India, with the lowest $\mathrm{LC}_{50}$ value of $2.538 \times 10^{3} \mathrm{POBs} / \mathrm{ml}$, followed by the isolate from Coimbatore in Tamil Nadu, India $\left(2.965 \times 10^{3} \mathrm{POBs} / \mathrm{ml}\right)$, and the Rajasthan isolate with $\mathrm{LC}_{50}$ value of $13.08 \times 10^{3} \mathrm{POBs} / \mathrm{ml}$ was the least effective. Geetha and Rabindra (1999) found that among the $11 \mathrm{HaNPV}$ isolates collected from different regions in India, Negamam and Ooty isolates from Tamil Nadu were significantly more virulent with $\mathrm{LC}_{50}$ values of 83.807 and $93.926 \mathrm{POBs} / \mathrm{cm}^{2}$, respectively. The Rajasthan isolate was the least potent with $\mathrm{LC}_{50}$ value of $111.778 \mathrm{POBs} / \mathrm{cm}^{2}$.

All these studies indicate that there is a significant variation in $\mathrm{LC}_{50}$ values with overlapping fiducial limits and the use of locally produced NPV appeared to be more useful for managing the respective insect pests than the commercially available NPV from other parts of the country. Geetha and Rabindra (1999) also reported overlapping fiducial limits of $\mathrm{LC}_{50}$ values of eight $\mathrm{HaNPV}$ isolates among the 11 isolates evaluated. The variation in the activity of different isolates may be due to different reasons. Inherent genetically controlled factors may logically be an important reason. The other reason may be that the different isolates had different number of passages in the host either under natural conditions or in the laboratory (Geetha and Rabindra 1999). In Log concentration-probit mortality relationship, the lower the slope value, the greater is the variability. Normally, the slope values were very low in bioassay studies with insect pathogens (Burges and Thompson 1971). Battu and Ramakrishna (1987) reported the respective slope values of $0.1674,0.4078$, and 0.1215 for 6-, 9-, and 11-day-old S. obliqua larvae, respectively, when inoculated with its own NPV. Arora et al. (1997) reported slope values varying from 0.58 to 0.96 for the five $H a \mathrm{NPV}$ isolates evaluated against the second instar larvae of $H$. armigera. The low slope of dosage-mortality curves for insect pathogens often indicates a more stable host-pathogen relationship.

\subsubsection{Comparative Analysis of Viral Proteins of Different NPV Isolates}

The crystalline matrix of the occlusion body mainly consists of a single protein, called polyhedrin or granulin. These proteins have about 245 amino acids ( $29 \mathrm{kDa})$ 


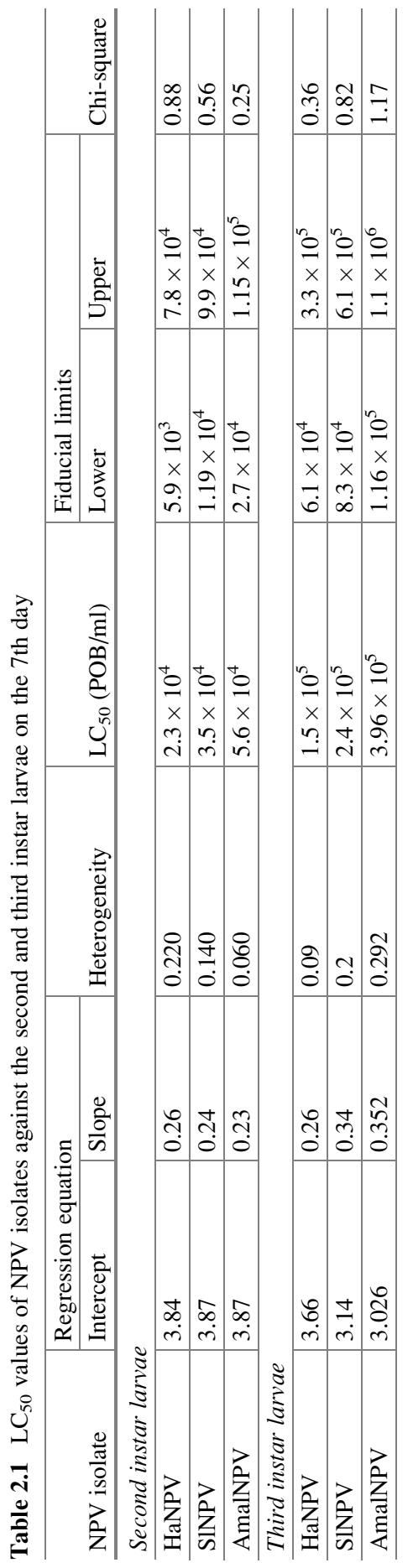


Table 2.2 $\mathrm{LT}_{50}$ values of NPV isolates against the second and third instar larvae

\begin{tabular}{|c|c|c|c|c|c|c|}
\hline \multirow{3}{*}{$\begin{array}{l}\text { Virus concentration } \\
(\mathrm{POB} / \mathrm{ml})\end{array}$} & \multicolumn{6}{|c|}{$\mathrm{LT}_{50}(\mathrm{~h})$ values } \\
\hline & \multicolumn{3}{|c|}{ Second instar larvae } & \multicolumn{3}{|c|}{ Third instar larvae } \\
\hline & HaNPV & SINPV & AmalNPV & HaNPV & SINPV & AmalNPV \\
\hline $1.8 \times 10^{8}$ & - & - & - & 123.60 & 132.72 & 128.64 \\
\hline $1.8 \times 10^{7}$ & 122.64 & 128.58 & 132.52 & 134.25 & 140.4 & 144.0 \\
\hline $1.8 \times 10^{6}$ & 131.28 & 133.62 & 136.64 & 136.42 & 143.0 & 148.64 \\
\hline $1.8 \times 10^{5}$ & 142.32 & 146.76 & 149.72 & 150.0 & 156.12 & 162.42 \\
\hline $1.8 \times 10^{4}$ & 153.30 & 158.60 & 162.72 & 161.22 & 176.08 & 182.06 \\
\hline $1.8 \times 10^{3}$ & 191.18 & 195.60 & 199.20 & 216.07 & 228.96 & 236.16 \\
\hline $1.8 \times 10^{2}$ & 230.68 & 234.60 & 238.06 & - & - & - \\
\hline
\end{tabular}

and are hyper-expressed during the very late phase of virus infection and are not required for virus replication (Rohrmann 1986, 1992; Funk et al. 1997) and constitute up to $18 \%$ or more of total alkali-soluble protein late in infection (Quant et al. 1984). It is a highly stable protein, insoluble in many solvents at neutral $\mathrm{pH}$ values and physiological conditions, highly resistant against the action of proteolytic enzymes, and at the same time it is highly sensitive to alkaline conditions (Bergold 1947; 1948). At ICRISAT, with an aim of production of polyclonal antibodies against poly-occlusion body protein (polyhedrin) for the development of diagnostic and quality control tools during mass production of NPVs, the purification protocol for polyhedrin protein was standardized (Sridhar Kumar et al. 2007) with slight modifications to the methods suggested by Summers and Egawa (1973), Harrap et al. (1977), and Quant et al. (1984). In $12 \%$ SDS-PAGE analysis, the denatured purified protein preparations of three viruses resolved as single band (Fig. 2.6) with estimated molecular weights of $31.65 \mathrm{kDa}$ $( \pm 0.00)$ (HearNPV), $31.29 \mathrm{kDa}( \pm 0.00)$ (SpltNPV), and $31.67 \mathrm{kDa}( \pm 0.295)$ (AmalNPV). This report is similar to that reported by Tuan et al. (1999) for three lepidopteran NPVs such as HaNPV, SINPV, and SeNPV. Recently, Ashour et al. (2007) reported the molecular weight of $32 \mathrm{kDa}$ for recombinant and wildtype A. californica NPV (AcAaIT and AcMNPV). In addition to the major polyhedrin, they are contaminated with some minor low molecular weight peptides of about 7-27 kDa and a high molecular weight peptide of about 60-70 kDa, which could be the degraded peptides or dimmers of the $31 \mathrm{kDa}$ polyhedrin protein. This has revealed that these three NPVs have six to eight minor polypeptides.

To characterize NPV protein structure for the purpose of providing reliable identification methodology and developing specific and sensitive serological detection techniques, the nucleocapsids of different $\mathrm{HaNPV}$ isolates across India were purified by alkali dissolution of POBs followed by 25-60\% sucrose gradient centrifugation (Sireesha 2006). Purified samples of HaNPV from ICRISAT, University of Agricultural Sciences of Dharwad, Tamil Nadu Agricultural University, Panjabrao Deshmukh Krishi Vidyapeth in Akola, Punjab Agricultural University, and Gujarat Agricultural University (UASD, TN, AK, PAU, and GAU) were analyzed in $12 \%$ SDS-PAGE gels for proteins. This has revealed that all the 


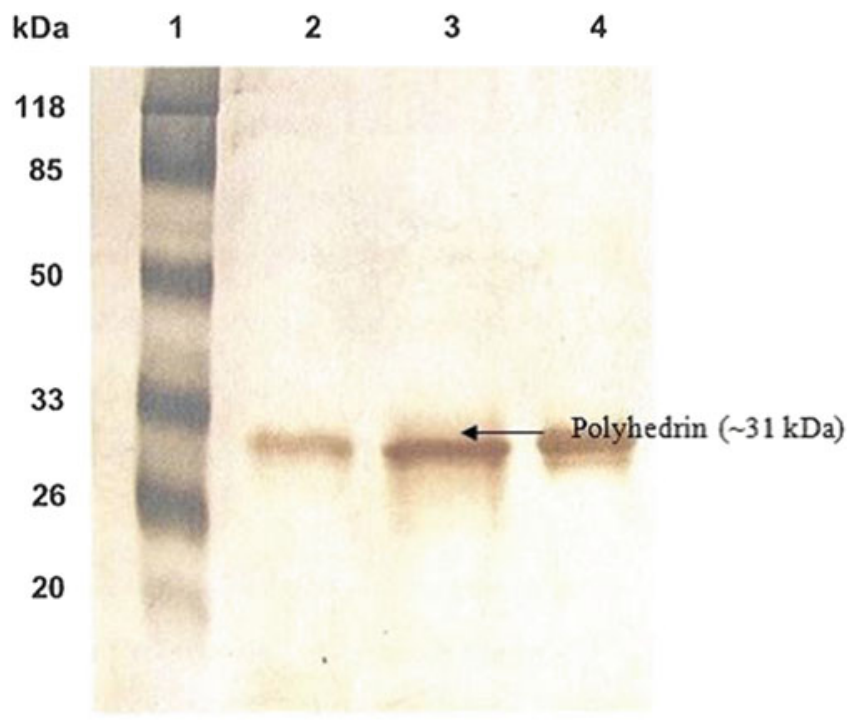

Fig. 2.6 SDS-PAGE (12\%) profile of polyhedrin protein preparations of NPVs. Purified polyhedral protein (polyhedrin) preparations of NPVs were separated in $12 \%$ SDS-PAGE. The polyhedrin was appeared as single protein band in silver stained gel and the protein band at $\sim 31 \mathrm{kDa}$ was indicated with arrow mark. Lane 1: Protein molecular weight marker; Lane 2: HaNPV polyhedrin; Lane 3: SINPV polyhedrin; Lane 4: AmalNPV polyhedrin

isolates have 4 to 5 major polypeptides of $42.32( \pm 0.92) \mathrm{kDa}, 34.74( \pm 0.27) \mathrm{kDa}$, $31.77( \pm 0.44) \mathrm{kDa}, 30.66( \pm 0.27) \mathrm{kDa}$, and $19( \pm 1.41) \mathrm{kDa}$ and several minor peptides. Three major proteins were present in all except in GAU isolate. The molecular weights of the major proteins were nearly similar, but not identical. GAU sample was unique in that it lacked the ca. 42 and ca. $34 \mathrm{kDa}$ proteins. Several minor proteins were also seen in the gel (indicated with arrows). GAU isolate recorded one extra protein of $19( \pm 1.41) \mathrm{kDa}$. It was also noticed in other isolates, but it was not as conspicuous as in the case of GAU. Summers and Smith (1978) studied the structural polypeptides of eight insect baculoviruses which revealed a complex but unique composition of 15-25 bands with molecular weights ranging from 15,000 to 1,60,000 Da. A. californica MNPV capsids contained two major polypeptides VP18.5 and VP37; Rachiplusia ou MNPV capsids contained VP16, VP18, VP30, and VP36; A. gemmatalis MNPV contained one major capsid protein VP29; and the major capsid proteins of H. zea SNPV were VP16, VP28, and VP63.

Kelly et al. (1980) observed a high degree of similarity between the polypeptides of two SNPVs of H. armigera and H. zea. Monroe and McCarthy (1984) characterized the structural polypeptides of $H$. armigera NPV from India, China, and USSR. For Indian isolate, the molecular weights of polypeptides ranged from 14.2 to $90.0 \mathrm{kDa}$. Harrap et al. (1977) purified polyhedron proteins from three closely related insect pest NPVs, viz., S. littoralis, Spodoptera exempta, and Spodoptera frugiperda, after dissolution in $0.05 \mathrm{M}$ sodium carbonate and separation on 7 and 
$10 \%$ SDS-PAGE. They did not observe significant differences between the sizes of major proteins of the three viruses whose molecular weights ranged from 28 to $29 \mathrm{kDa}$. They also concluded that the smaller polypeptides of each virus preparation represented an initial breakdown product derived by proteolytic cleavage of larger molecule. Maskos and Miltenburger (1981) compared the polyhedral polypeptides of L. dispar, M. brassicae, and A. californica NPVs using SDS-PAGE. They observed eight distinct polypeptide bands with major polypeptides in the range of 28.0-30.0 kDa. They found characteristic differences between the species for minor polypeptides having molecular weights in the range from 12.4 to $62.0 \mathrm{kDa}$. Caballero et al. (1992) observed similar mobility profiles of the occluded virion polypeptides and polyhedrins of four S. exigua NPV isolates originating from the United States, Thailand, and two locations in Spain.

\subsubsection{Efficacy of NPV Under Different Storage Conditions}

Unlike chemical pesticides, viral pesticides often have a shorter half-life of infectivity (Shieh 1978) that requires special attention for commercial operations. Viral insecticides cannot be developed commercially until formulations of these are physically, chemically, and environmentally stable in storage and distribution. At ICRISAT, $H a \mathrm{NPV}$ storage studies were conducted over a period of time under different set of storage conditions, and their efficacy was tested against the second instar H. armigera larvae at the rate of $10^{6} \mathrm{POB} / \mathrm{ml}$ at an interval of 2 months up to 10 months, and the mortality data on the 5th, 7th, and 9th days were analyzed using two-way ANOVA. Variation in the efficacy was observed when stored under different conditions of storage over a period of time (Table 2.3). NPV sample, which was stored under refrigerated condition, could maintain its efficacy up to 8 months (100\%), and by the tenth month, there was a slight decline ( $97.50 \%)$ but it was not significant, whereas NPV sample stored in earthen pot and at room temperature (both in amber-colored bottle and glass bottle) maintained its efficacy up to 4 months and after that virulence started to decrease. This decreased efficacy of samples stored under room temperature may be due to increased bacterial activity. When the samples were tested for the bacterial load, it was 3.47 times more in the samples stored at room temperatures after 6 months of storage. Gopali and Lingappa (2001b) also recorded decreased efficacy of NPV when stored under open house conditions, and it was opined that the change in the $\mathrm{pH}$ of viral suspension stored under refrigerated condition was very slow from acidic to normal (5-7) $\mathrm{pH}$ as against becoming excessively alkaline at ambient and earthen pot conditions. It was also reported that this change was mainly brought about by the growth of other microbes and warm conditions, which resulted in lowering of virulence of viral bodies. Attathom et al. (1990) also reported the same.

The stability of $H a \mathrm{NPV}$ appears to be dependent on the resistance of the inclusion body protein to decomposition. Many scientists (Stairs et al. 1981) reported that the inclusion body protein is broken down by weak alkalies but it 


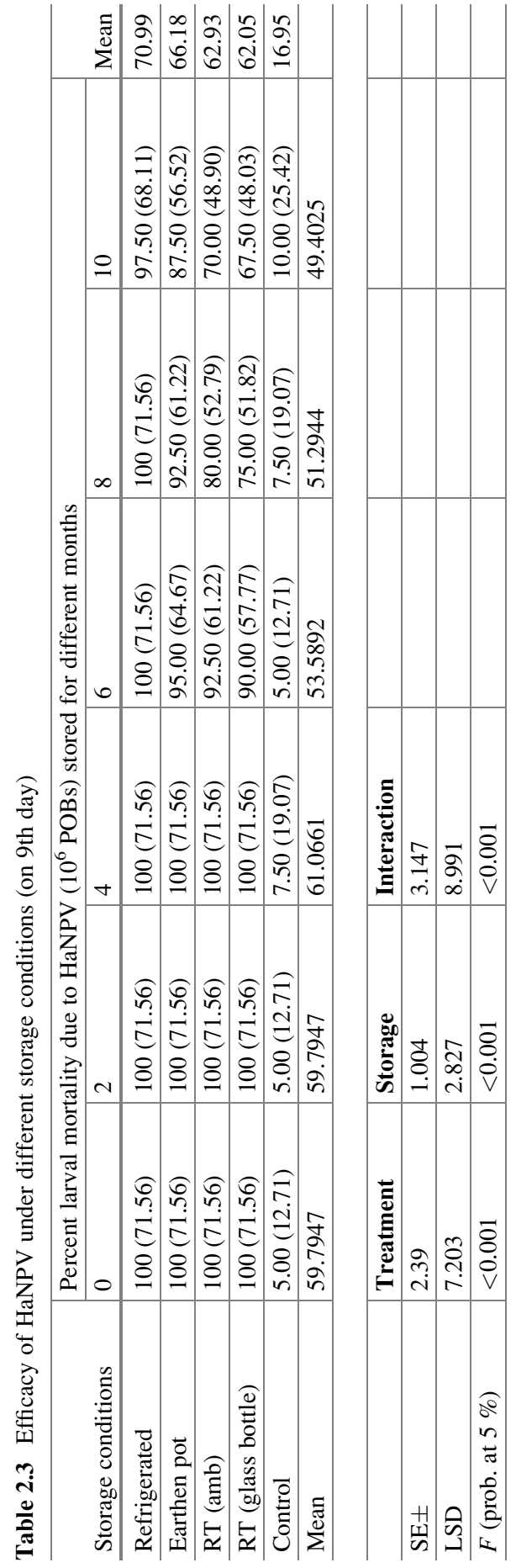


can withstand exposure to relatively strong acids and many other chemicals. Ebora et al. (1990) reported that virulence was greatest around neutral $\mathrm{pH}$ and reduced when subjected to high $\mathrm{pH}$ (12). Shapiro and Ignoffo (1969) showed that activity of virions of $\mathrm{HaNPV}$ released from polyhedral cover lost about half of their activity when stored for 60 days at $37^{\circ} \mathrm{C}$, whereas virus particles covered with polyhedral layer retain their activity for a longer period withstanding freezing and prolonged normal field temperature than free virions (Yendol and Hamlen 1973). Many scientists reported that virus could be preserved for more than 10 years at $4{ }^{\circ} \mathrm{C}$ without loss in virulence (Narayanan 1985). Gudauskas and Cannerday (1968) found the thermal inactivation point of $\mathrm{HaNPV}$ to be $75-80{ }^{\circ} \mathrm{C}$ for $10 \mathrm{~min}$. The virulence of virus depends on the quality of the virus, storage conditions, and duration of storage, temperature, and $\mathrm{pH}$ of the product.

\subsubsection{Effect of Chemicals on the Shelf Life of NPV}

Information on screening of different chemicals or disinfectants on the shelf life of NPV products is scarce. It is known that the NPV produced in live insects may contain bacterial contamination (Podgwaite et al. 1983; Huber 1985) presenting a potential health hazard. Although these studies on L. dispar NPV and C. pomonella $\mathrm{GV}$ failed to detect human pathogens in the product, these viruses were produced under temperate conditions, and it might be anticipated that production in a near tropical situation would involve greater microbiological contamination problems. Grzywacz et al. (1997) quantified microbial contaminants level in S. littoralis NPV. They found $10^{6}-10^{9}$ bacterial colony forming units $/ \mathrm{ml}$ in virus suspension containing $2.1 \times 10^{9} \mathrm{POBs} / \mathrm{ml}$. They concluded that none of the bacterial contaminants found were harmful to cause potential health hazard. But some bacteria such as Bacillus cereus might be of concern, from the point of view of standardizing the product. Therefore, the development of production procedures, which reduce these contaminants to a lower, more consistent level, would be valuable in promoting a wider acceptance of viral insecticides as safe control agents. Simple centrifugation in water does not remove many microbial contaminants, as bacterial spores, etc., tend to pellet with NPV OB. Grzywacz et al. (1997) suggested the use of bacteriostatic agents and $\mathrm{pH}$ buffers to stabilize the formulations by reducing the multiplication of contaminants.

In our study, the HaNPV samples preserved in different chemicals over different periods of storage varied in their efficacy and bacterial contamination levels (Tables 2.4 and 2.5). The sample that was stored in distilled water maintained its virulence up to 10 months as evidenced by the 5th, 7th, and 9th day mortality. Cumulative mortality on the ninth day showed that the samples stored in $10 \%$ Dettol, $2 \%$ phenyl, $10 \%$ ethyl alcohol, and $10 \%$ methanol recorded $100 \%$ mortality followed by $10 \%$ acetone with 96.66 and $10 \%$ ethyl acetate with $90 \%$ mortality after the period of 2 months. NPV sample stored in $10 \%$ ethyl acetate consistently reduced its efficacy as evidenced by the mortality on the 5 th, 7 th, and 


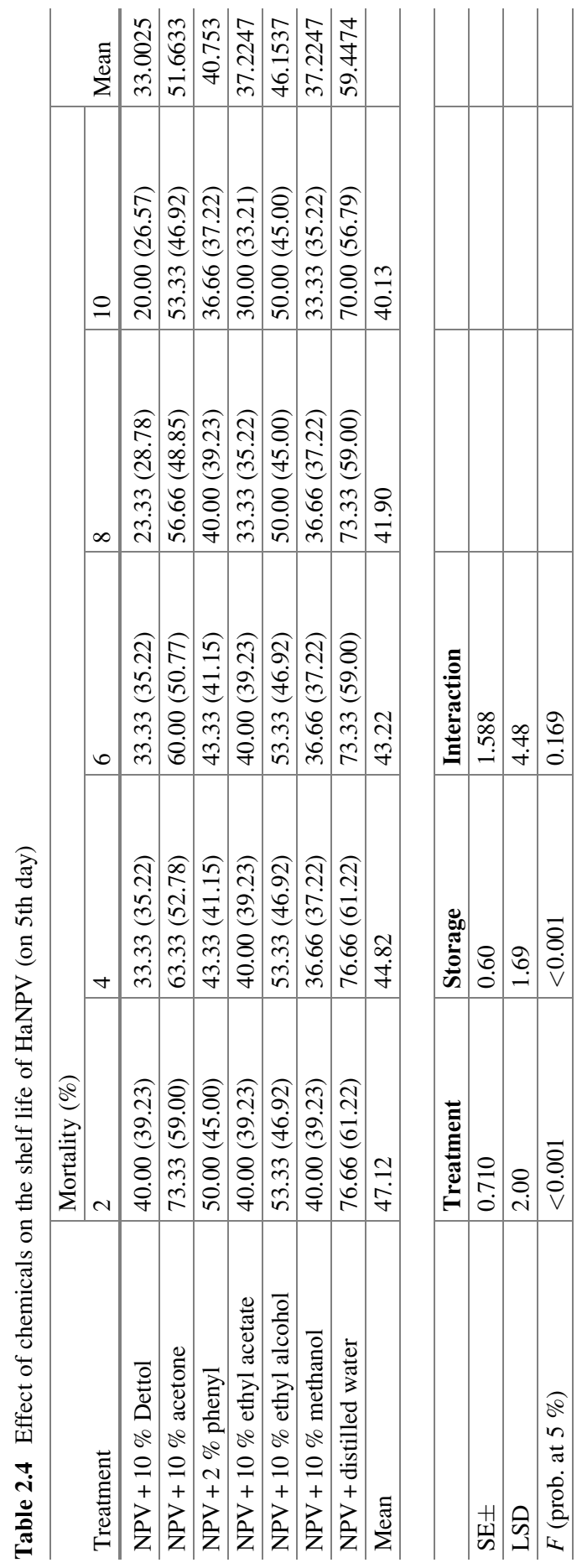


Table 2.5 Effect of chemicals on the bacterial contaminants in storage

\begin{tabular}{l|l|l|l|l}
\hline & \multicolumn{3}{|l|}{ Before storage } & \multicolumn{2}{l}{ After a period of 6 months } \\
\cline { 2 - 5 } Treatment & $\begin{array}{l}\text { No. of bacterial } \\
\text { colonies }\end{array}$ & $\begin{array}{l}\text { CFU/ } \\
\mathrm{ml} \times 10^{6}\end{array}$ & $\begin{array}{l}\text { No. of bacterial } \\
\text { colonies }\end{array}$ & $\begin{array}{l}\mathrm{CFU} / \\
\mathrm{ml} \times 10^{6}\end{array}$ \\
\hline NPV $+10 \%$ acetone & 20.33 & 1.01 & 19.66 & 0.98 \\
\hline $\begin{array}{l}\text { NPV }+10 \% \text { ethyl } \\
\text { alcohol }\end{array}$ & 22 & 1.1 & 21.33 & 1.06 \\
\hline $\begin{array}{l}\text { NPV }+10 \% \text { ethyl } \\
\text { acetate }\end{array}$ & 25 & 1.25 & 8 & 0.40 \\
\hline NPV $+10 \%$ Dettol & 23.33 & 1.16 & 25 & 1.25 \\
\hline NPV +2 \% phenyl & 18 & 0.9 & 7.33 & 0.35 \\
\hline $\begin{array}{l}\text { NPV }+10 \% \\
\text { methanol }\end{array}$ & 22 & 1.1 & 24.66 & 1.23 \\
\hline NPV + distilled water & 50.66 & 2.53 & 250 & 12.5 \\
\hline SE \pm & 0.433 & 0.02 & 0.349 & 0.01 \\
\hline LSD & 1.335 & 0.06 & 1.075 & 0.050 \\
\hline$F$ (prob. at $5 \%)$ & $<0.001$ & $<0.001$ & $<0.001$ & $<0.001$ \\
\hline
\end{tabular}

9th day. The results clearly indicated that, though all the chemicals could effectively reduce the bad odor problem in storage, the samples stored in acetone and ethyl alcohol only recorded 73.33 and $70.00 \%$ mortality, respectively, by the end of 10 months. However, NPV samples in all the treatments gave $90 \%$ mortality after storing for a period of 2 months (Tables 2.3 and 2.4). Ignoffo and Shapiro (1978) suggested the use of acetone in purification of NPV POBs. Acetone, being a potential antimicrobial agent, regulates bacterial infection and, being a lipid solvent, removes the lipid (fat cells) from the larval homogenate, thereby inhibiting bacterial lipid degradation and in turn the malodor. To address the problem of bacterial contaminants, Rao and Meher (2004) used $10 \%$ acetone solution. They could clear the lipid mass and leftover contaminating bacteria in the preparation and regulated the malodor problem. They confirmed the viability of the virus after 1 month of acetone clarification by conducting bioassay studies.

\subsubsection{Molecular Characterization}

Molecular-level identification, characterization, and evaluation of phylogenetic status of a particular baculovirus are also important for the establishment of purity of seed stock or master stock. Apart from the multiple or singly enveloped feature, NPV or GV cannot be identified visually from either light or electron microscopic studies. Microscopic and serological tools are unreliable for establishing the real identity of a given isolate and are not particularly helpful in providing clues about its host range and infectivity (Rovesti et al. 2000). Differences between viruses are usually reflections of intrinsic differences in their viral genomes. At one extreme, viruses may be readily distinguished by the nature of the nucleic acid (RNA or 
DNA) and its strandedness (single or double stranded), while more closely related viruses may differ only by small regions of distinct base sequences which can be defined only by more sophisticated techniques such as restriction endonuclease (REN) analysis or molecular probes, or sequencing of conserved and unique gene sequences which offers a relatively simple method for the identification and differentiation of baculoviruses (Smith and Summers 1978).

The only nucleic acid type found within the enveloped nucleocapsids of these viruses is a dsDNA molecule. DNA of baculoviruses is a large circular molecule. REN analysis can provide a measure for baculovirus DNA molecular weight. It has a more useful role in virus identification and ultimately in mapping of the viral genome. Examination of the DNA using these techniques has shown that many variants of a species may exist, for example, the MNPVs from A. californica, Trichoplusia ni, S. exempta, R. ou, A. falcifera, and Galleria mellonella can be considered to be variants of the same virus (Miller and Dawes 1978; Smith and summers 1979; Summers et al. 1980; Brown et al. 1984; Harrison and Bonning 1999). Many of the known baculoviruses could be grouped together depending on their degree of genetic relationship, which does not reflect the taxonomic grouping of their host/hosts (Zanotto et al. 1993). Among the NPVs with potential as pest control agents, the MNPVs isolated from M. brassicae (Lepidoptera: Noctuidae) and $H$. armigera (Lepidoptera: Noctuidae) were shown to be similar in terms of both biological activity and genomic homology (Smith and Summers 1982; Figueiredo et al. 1999; Rovesti et al. 2000). For identification of a particular NPV strain, the bioassay studies and REN profiles of different NPV species have been studied and compared by several investigators (Shapiro and Ignoffo 1970; Hughes et al. 1983; William and Payne 1984; Rabindra 1992; Somasekhar et al. 1993; Arora et al. 1997; Geetha and Rabindra 1999; Sudhakar and Mathavan 1999; Figueiredo et al. 1999; Rovesti et al. 2000). The existence of genetic variants with different biological activities may have important implications for development of bio-pesticides both in the possibility to select better naturally occurring strains and as a source material for genetic manipulation (Guo et al. 2006).

In order to establish the purity of seed stock or master stock of $\mathrm{HaNPV}$ used for commercial insecticide preparations, an attempt was made at ICRISAT by molecular characterization of $H a \mathrm{NPV}$ done by isolation, cloning, sequencing of polyhedrin gene, and evaluation of the phylogenetic status (Sridhar Kumar 2008). Considering the sizes of previously published polyhedrin gene sequences, most amplification products were between 730 and 750 bp long. Gene sequencing analysis of selected clones resulted in 744-nucleotide-long ORF with a predicted coding capacity for a polypeptide of 247 amino acids as in the AmalNPV (AF118850). Similarly, Rivkin et al. (1998) reported a 246 amino acid polypeptide in a local strain of Israeli HaNPV polyhedrin, and Bansal et al. (1997) reported same length of amino acid polypeptide in SINPV polyhedrin. The polyhedrin is the major protein of the virus $\mathrm{OB}$ and is the most conserved protein of NPVs (Rohrmann 1992). After the first report about localization of the polyhedrin gene in AcNPV, its nucleotide sequence was determined (Vlak and Smith 1982; Hooft van Iddekinge et al. 1983). Polyhedrin/granulin is a protein of about 245-250 amino 
acids and appears to be the most highly conserved baculovirus protein. These characteristics lead to the use of polyhedrin or granulin sequences as the base of baculovirus phylogenetic studies, since this is the gene from which a larger number of different examples are available for comparison (Zanotto et al. 1993). Although polyhedrin gene is still considered a reasonable marker for identification of an NPV and its neighbors, Herniou et al. (2003) and Lange et al. (2004) argued that it might not be the best baculovirus gene for phylogenetic studies because polyhedrin phylogenies often disagree with other gene phylogenies. While other phylogenetic analyses consistently group AcMNPV and BmNPV together, phylogenies based on polyhedrin have AcMNPV as a sister group to the rest of the group-I NPVs (Herniou et al. 2003). Phylogenies based on combined sequences of shared genes have been found to be more robust than those based on the sequences of individual genes (Herniou et al. 2003).

PCR, when combined with the use of REN analysis, can provide considerable resolution for use in diagnostics; it is relatively simple to use and can provide quick results. Not surprisingly, this approach is now widely used for detection and identification of a range of insect viruses (Kool et al. 1991; Williams 1993; De Moraes and Maruniak 1997; Bulach et al. 1999). Christian et al. (2001) developed a rapid method based on PCR-RFLP analysis for identification and differentiation of HaSNPV and AcMNPV groups by using a set of redundant primers to highly conserved region of polyhedrin gene. Based on REN analysis, Rovesti et al. (2000) reported that the $H a \mathrm{NPV}$ isolate was shown to be a mixture of many closely related genotypes but individual genotypes remained unchanged on passage in either H. armigera or M. brassicae. Doyle et al. (1990) noted that when MbMNPVD was passed in Orthosia cruda, there were minor changes in the restriction enzyme profile, which was attributed to the selection of a different variant. However, bioassay studies of Rovesti et al. (2000) showed that the two viruses HaMNPV and MbMNPV were successfully replicated in $H$. armigera, $M$. brassicae, and $H$. zea, resulting, in each case, in progeny virus which was essentially similar to the inoculum. Therefore, a viral insecticide based on these NPVs from $H$. armigera and $M$. brassicae would be more appropriately targeted against both insects. Similarly, Murillo et al. (2001) have reported that REN profiles of two SeNPV isolates (SeUZB and SeSP3) in Uzbekistan and Spain and MbNPV (Mb-PL) in Poland were closely related to previously described Spanish isolates of SeNPVs. At the same time, the Pst-I and Bgl-II profiles of SeUZB and Mb-PL were identical and very similar to the REN profiles of MbMNPV strain which is the active component of Mamestrin ${ }^{\mathrm{R}}$, a commercial bio-insecticide in France (NPP, Nogueres, France). In addition to SeMNPV, S. exigua is susceptible to other NPVs such as A. californica MNPV (Smits and Vlak 1987) and MbMNPV (Wiegers and Vlak 1984). In another case, AcMNPV and BmNPV also show a high degree of genomic homology and different REN fragment profiles but do not share an overlapping host range and can be regarded as two different species. It is interesting to note that only minor changes in the virus genome, namely, one or two amino acid substitutions in the AcMNPV helicase p143, are sufficient to expand the host range of AcMNPV to Bombyx mori larvae (Kamita and Maeda 1997; Arguad et al. 1998). 
Clearly, there are problems in naming a baculovirus simply on the basis of the host from which it was originally isolated, and therefore, greater vigilance should be taken in naming new (and old) viruses. For example, studies on viruses from members of the same or different host species show similarity or variability in morphology, virulence, and biological characteristics (Shim et al. 2003). Many of the known baculoviruses could be grouped together depending on their degree of genetic relatedness, which does not reflect the taxonomic grouping of their host/ hosts (Zanotto et al. 1993). Based on the above reports, one can comment like "variants of baculoviruses with heritable similarities in virulence and variations in host range arise spontaneously in nature." In the earlier days of baculovirology, it was believed that baculoviruses could only infect a single host species and that no cross-infection occurred. This generalized the use of binomial Latin names of the insect species hosts to describe the new viral isolates. However, this practice can affect our understanding of baculovirus biology and can also lead to confusion upon studying the classification and taxonomy of baculoviruses (Federici and Hice 1997) and should be changed by more reliable methods based, for instance, on the genotypic characteristics of the viruses. A useful means for identification or description of baculoviruses is REN analysis of viral DNA, as firstly demonstrated by Lee and Miller (1978). This method has proved to be very useful not only for distinguishing distinct NPV species but also different strains of one virus or even different genotypes within the same virus isolate (Smith and Crook 1988; Munoz et al. 1998). In general, baculovirus wild-type populations, from different geographical isolates of the same virus and within a single isolate, where several genotypic variants frequently coexist, show a considerable genetic heterogeneity. This heterogeneity is due to the enormous plasticity displayed by baculoviruses genomes which can undergo deletions (Munoz et al. 1998), insertions (Jehle et al. 1995), point mutations, recombinations (Croizier and Ribeiro 1992), etc. This plasticity suggests that field isolates may be adapting to host and environmental conditions and that those isolates containing heterogeneous populations may be more valid for viral survival in the field (Possee and Rohrmann 1997). Investigations of geographic variability and the role of genotypic differences in the biology of baculoviruses are an important area of current research. Such studies may provide insight into the evolution of baculoviruses and their hosts and may also aid in the development of more effective virus strains for biological control of insects.

\subsection{Production Technologies}

Historically, several entomopathogenic viruses have been produced in susceptible host insects, because of the following reasons: (1) The insect host is an efficient virus producer (Ignoffo and Couch 1981). (2) Automation of in vivo rearing and in vivo production systems is feasible (Powell and Robertson 1993). Some baculovirus species may be produced in insect cell cultures, but the associated 
costs are relatively high (Hink 1982). Therefore, all NPVs that have been developed as commercial products thus far have been produced in host larvae.

\subsubsection{In Vivo Mass Production}

In vivo virus production has several advantages like (1) Successful use of viruses produced in the host to control insect pests (Ignoffo and Couch 1981; Bell 1991). (2) Research is continuing in this area to produce more efficient systems, which makes this approach an economically viable one. (3) In many areas of the world, virus production in the host is the only approach feasible (Katagiri 1981; Moscardi et al. 1981). In vivo mass production systems have changed little over the past 30 years. The development of semi-synthetic artificial diets by Vanderzant et al. (1962) resulted in rearing and virus production systems for the cotton bollworm (H. zea), the tobacco budworm (Heliothis virescens), and the cabbage looper (T. ni) by Ignoffo (1965). The initial rearing system was made more efficient by the introduction of disposable multi-celled plastic trays (Ignoffo and Boeing 1970), automation in rearing, and automation in virus inoculation and harvesting. Optimal virus production is the result of interrelationships of host-pathogenenvironment, and each factor in this triad must be assessed for influence on quantity and quality of the product. Research in these areas has been summarized (Shapiro et al. 1986; Shapiro and Bell 1981, 1982). A broader and more complete account of some aspects on virus production and role of virus in insect pest control has been given by Burges (1981). Subsequent development and industrialization for mass rearing process, improvements in viral recovery procedures, and formulation of the viral product made it possible for commercialization of $H a N P V$ (Shieh 1978). Further, Ignoffo and Couch (1981) improved the method of mass production of baculovirus of Helicoverpa from the laboratory-reared Helicoverpa larvae through which 7-9 times more active virus and 2-5 times more POBs were obtained from dead and diseased larvae.

Field collection of diseased larvae led to contamination with adventitious agents which would pose a major problem in terms of safety and quality control, and as such, it was not desirable for HaNPV production (Sherman 1985). Because of the developments in semi-synthetic diet, containerization, and automation, laboratoryreared insects have been the hosts of choice. The advantages of these insects are (1) Laboratory-reared insects tend to be larger than field-collected insects, because of the selection and adaptation to the laboratory environment (diet, temperature, humidity, and photoperiod). (2) They are normally disease free, which should result in virus product that is free from other pathogens. (3) The growth and development of laboratory-reared insects tend to be faster than field insects, because of selection. (4) Virus yield among laboratory-reared insects tends to be greater than among field insects, since virus yield is dependent on host biomass (Hedlund and Yendol 1974; Shapiro and Bell 1981). Although laboratory-colonized insects provide several advantages over field insects as virus producers, field insects have also been used 
successfully to produce NPV from larvae of the potato tuber moth (Phthorimaea operculella [Zeller]) in Australia (Matthiessen et al. 1978), the velvetbean caterpillar (A. gemmatalis) in Brazil (Moscardi et al. 1981), and the European pine sawfly (N. sertifer) in the United States (Rollinson et al. 1970) and CPV from the pine caterpillar (Dipodomys spectabilis) in Japan (Katagiri 1981) on natural foliage.

Different methods of mass production of baculoviruses, according to Pawar and Thombre (1992), are (1) large-scale rearing of insects in the laboratory, (2) field collection of host larvae from infested crops and infecting them in the laboratory, and (3) field collection of diseased larvae from infested fields. Large collection of insect viruses at the rate of 20,000 host larvae have been reported from different crops, viz., cotton, sunflower, pigeonpea, and chickpea (Ignoffo 1966a, b; Anderson et al. 1972; Battu 1992). Battu (1992) reported relatively lower levels of POBs obtained from field-collected, diseased, and dead insects. The number of larvae required to produce one larval equivalent (LE) $\left(6 \times 10^{9} \mathrm{POBs}\right)$ of virus from fieldcollected larvae was higher (2.97) than laboratory-reared ones (2.14) since fieldcollected larvae were of different sizes unlike the uniform stages in the laboratoryreared ones (Gopali and Lingappa 2001a). At ICRISAT, for effective mass multiplication of AmalNPV, the field-collected larvae are released into an aluminum or polythene grid/enclosure $(10 \mathrm{~cm}$ height $)$ to confine the larvae inside the shaded enclosure and feed with plants already inoculated with the virus. The field technique for rearing larvae is advantageous, particularly in avoiding the handling of huge larval populations, rearing, and inoculation. This would also facilitate farmlevel production and access to the bio-pesticide at the village level (Rao 2006). The laboratory-level mass production technique for AmalNPV has been standardized by Veenakumari et al. (2006). In situ field-level mass production of AmalNPV in a groundnut ecosystem was developed for the first time at Project Directorate of Biological Control (PDBC), Bangalore, India (Veenakumari et al. 2007).

The virus used for the inoculation must confirm the quality control specifications of viral products as reported by Shieh and Bohmfalk (1980). The inoculation dose is expressed in units of $\mathrm{POB} / \mathrm{ml}$, and the optimal dose varies with the virulent virus and age of the host (Ignoffo and Couch 1981). Angelini and Labonne (1970) suggested that the best method to propagate the virus was to spray a suspension on larval diet. They could get the larval mortality after 7-8 days. Shapiro and Bell (1981) reported that surface treatment is an efficient system that is easily automated and requires much less virus than diet incorporation. However, Odak et al. (1984) used soaked chickpea seeds treated with HaNPV to feed Helicoverpa larvae and found that the method was effective for mass production of virus. Bioassays were used to determine the activity of each batch of virus. Several modes of administration of virus were tried using different larval instars, viz., surface treatment, diet incorporation, and direct feeding (Ignoffo 1966a). Earlier instars were highly susceptible to the virus (Rabindra and Subramanian 1974) with $\mathrm{LT}_{50}$ shorter than older ones. Narayanan (1979) report that the early instars recorded $100 \%$ mortality, whereas the late instars particularly from the fifth instars pupated and gave rise to malformed adults with short and ruffled wings. The effect of NPV was directly related to the age of the larvae at the time of infection (Battu 1990). Further, Battu 
(1992) reported that increasing dosages are required to kill the older larvae. The relative resistance of 8-day-old larvae was 2,000 times more than that of 1-day-old larvae. Further, Battu observed that the fifth and sixth instar larvae could not be infected with the virus even at higher concentrations. Rabindra and Subramanian (1974) inoculated the fourth instar larvae with a dose of $10^{6} \mathrm{POBs} / \mathrm{ml}$ to harvest maximum yield. The $\mathrm{LC}_{50}$ values for the first and third instars of $H$. armigera were $8.3 \times 10^{3}$ and $28.6 \times 10^{5}$ POBs per larva, respectively (Backwad 1979). Narayanan (1979) found that the optimum dose of inoculum required for obtaining maximum harvest of virus from the fourth instar larvae was $5 \times 10^{4} \mathrm{POBs} /$ cavity/larva by the diet surface contamination method, whereas Shieh (1978) used $5 \times 10^{5}-5 \times 10^{6}$ $\mathrm{POB} / \mathrm{ml}$ inoculum in each cavity and observed that there was significant interaction between the age of the larvae and dose of the virus with the recovery of POB.

Taun et al. (1989) described the pathogenicity of HaNPV to H. armigera using three different inoculation methods. The $\mathrm{LD}_{50}$ values of the fourth instar larvae that were fed on diet containing NPV or maize kernels soaked in virus suspension were $1.85 \times 10^{6}$ and $2.55 \times 10^{5}$ POBs per larva, respectively. The inoculum-imbibing method was more sensitive and convenient for inoculating the pest with virus, whereas Jayaraj and Sathiah (1993) described the three methods of inoculation, viz., head dipping, oral feeding, and diet surface contamination, and the latter method was the most economical and convenient for easy application. Ignoffo (1966b) estimated that at least $6 \times 10^{9}$ virus polyhedra were produced per larva in late instars of $H$. zea, and he defined it as "one larval equivalent." The average yield of virus per larva infected after 5-7 days at $30^{\circ} \mathrm{C}$ was $1.5 \times 10^{9}$ polyhedra (Ignoffo 1973). Teakle et al. (1985) observed that the least yield of $1.18 \times 10^{7} \mathrm{POB} / \mathrm{insect}$ was from younger larvae of $H$. armigera compared to $3.6 \times 10^{9} \mathrm{POBs} /$ insect from grown-up larvae, whereas Shieh (1978) recovered $5 \times 10^{9} \mathrm{POBs} / \mathrm{larva}$, indicating that the yield of POBs was directly related to the age of the infected larvae. The host insect, insect diet, insect age and virus dosage, incubation, environment, and preservation of virus infectivity were some of the major factors that optimize the production of HzNPV (Carter 1984). The virus yield increased exponentially with the age of larva at dosing in the range of zero to six days, the overall increase being approximately 100-fold (Teakle and Byrne 1989). Battu (1990) reported an average yield of $1.81 \times 10^{9} \mathrm{POB}$ per larva of $H$. armigera. Similarly, Pawar and Thombre (1992) reported that $H a \mathrm{NPV}$ yields per larva ranged from $0.95 \times 10^{9}$ to $3.5 \times 10^{9}$. Gopali and Lingappa (2001a) suggested $10^{8} \mathrm{POBs} / \mathrm{ml}$ as the optimum dose required for the third and fourth instar larvae to achieve quicker and higher mortality of larvae for virus production, and among different instars of H. armigera, the fourth instar larva was found ideal for virus production as it yielded higher quantity of virus per larva $\left(2.81 \times 10^{9} \mathrm{POB}\right)$. In vivo mass production and control efficacy studies of $S$. litura NPV (SlNPV) were positively correlated with larval weight from the third instar to the fifth instar larvae; a maximum yield of $1.4 \times 10^{9} \mathrm{POBs} / \mathrm{ml}$ was obtained with the early fifth instar larvae individually infected by diet-incorporation of inocula of $3 \times 10^{6} \mathrm{POBs} / \mathrm{ml}$ for 7 days of incubation at $30^{\circ} \mathrm{C}$ (Tuan et al. 1998). Similarly, a maximum yield of $5.57 \times 10^{9} \mathrm{POBs} /$ larva was obtained at the inoculum dose of $1966.2 \mathrm{POB} / \mathrm{mm}^{2}$ of $S$. litura NPV when exclusive harvest of cadaver was 
done (Senthil Kumar et al. 2005). Jun et al. (2007) reported that the volume of POBs of SIMNPV harvested on the 5th day of the postinoculation period was significantly lower than that harvested on the 7th day of the post-incubation period which was significantly lower than that harvested after larval death, and a similar trend was observed in biological activity by dosing the fifth instar larvae. To study the influence of virus inoculation method and host larval age on the productivity of the NPV of the teak defoliator, Hyblaea puera (Cramer) was determined by different methods of inoculation (Biji et al. 2006).

At present in India, in vivo propagation is being practiced for NPV mass production at commercial scale and even at farmer level. Healthy larvae reared in the laboratory or collected from the fields are fed with low dose of NPV, and the virus produced in the insect is harvested and its concentration is estimated by counting POBs using a light microscope fitted with a hemocytometer. Recently, local production and utilization of NPV gained momentum in India through participation of scientists, farmers, NGOs, and state agricultural and extension departments. In the fields, natural mortality of Helicoverpa and Spodoptera can be seen due to infestation of disease-causing virus particles. Such larvae can be collected and may be utilized for in vivo mass propagation and again for checking their efficacy against pest populations. ICRISAT (Rao et al. 2007) trained several national agricultural research and extension systems (NARES) scientists and farmers on bio-pesticide production and established 96 village-level NPV production units in India and Nepal to encourage their use. As the selection of virulent strain of NPV is key to the development of effective bio-pesticides, local strains are always preferred for sustainability, adaptability, and efficacy under a given set of agroecosystem and hold an ample scope for their widespread multiplication and commercial use in a particular region (Gupta et al. 2007, 2010). It is well recognized that factors such as the geographic origins of both the virus and host can affect the characteristics of the dose-response curve and the period of survival of infected hosts (Maeda et al. 1990). For production of $\mathrm{HaNPV}$ and SlNPV, a host insect larva has to be multiplied on artificial or semisynthetic diet or soaked chickpea seeds. Crude $H a \mathrm{NPV}$ is commercially produced at Dr. Panjabrao Deshmukh Krishi Vidyapeeth, Krishi Nagar, Akola (Maharashtra), and at Agricultural Research Station, Gulbarga (Karnataka), by following the procedures: host insect multiplication, virus inoculation and harvest, extraction and purification of virus, and standardization of NPV.

\subsubsection{Problems Associated with Commercialization of In Vivo-Produced NPV Products}

In vivo mass production of NPVs is labor intensive and involves mass rearing and infection of insect larvae, which account for high production costs. In addition, the products have some quality and storage issues which severely affect the efficacy 
and quality of the products. One of the major problems involved in harvesting virus from dead larvae was that they were often heavily contaminated with bacteria. Purification methods based on centrifugation were found to be less effective in removing bacteria (Sireesha 2006; Sridhar Kumar 2008). Other problems are inconsistency in the yield and malodor during production and even in the finished product also. Another important problem associated with the commercialization of NPV products is the lack of proper diagnostic systems to quantify the virus titer, microscopic counting procedure used to screen the larvae for NPV infection, and quality control of the viral insecticide batches which has low-detection efficiency, unknown specificity, and is laborious and requires considerable skill (Wigley 1976). Because of this, many NPV products produced in India have poor efficacy and are found to be ineffective under field conditions. To overcome this problem and for effective production of viral insecticides, it is necessary to have an efficient strategy for virus production, combined with rapid and specific diagnostic and quality control system (Shieh 1989).

Microbial pesticides including NPVs and GVs have now been brought under the ambit of the Central Insecticide Act, 1968. Commercialization of microbial pesticides is possible only after registration with the Central Insecticide Board (CIB) in India, a body constituted under the insecticides act that regulated their manufacture and use. Section $9(3 \mathrm{~b})$ of the act specifies a minimum quantity of active ingredient in the formulation. Many of the viral products available in the markets in developing countries were classified as weak, with poor efficacy, questionable quality control (Harris 1997), and are failing to meet acceptable standards (Kern and Vaagt 1996). Unless this matter is addressed effectively, there is serious danger in these countries that poor quality products with their inevitable failures will erode the farmer's confidence in microbial control products such as NPV and significantly retard the promotion of this potential technology. There has been a rapid growth in the production and use of NPV products in the last decade in India, but this has exacerbated quality problems (Kambrekar et al. 2007). The causes of poor quality lay in deficiencies in production technologies and poor quality control procedures. NPVs of Helicoverpa and Spodoptera have been most extensively researched and studied with regard to their efficacy, mass production, and compatibility with botanicals and other insecticides and against several nontarget organisms (Hunter-Fujita et al. 1998 and Saxene and Ahmad 2005). Pathogenicity of the isolates varies according to localities and therefore needs to be screened. Development of economical in vitro cell culture techniques for large-scale production of NPVs which will go a long way has not yet been developed for agricultural use. 


\subsubsection{Is In Vitro Production the Only Solution to Address Quality Control Issues?}

While several improvements in in-vivo production systems in insect larvae have been made in the past, these could not help to overcome the problems described above (Sireesha 2006; Sridhar Kumar 2008). Hence, it has been proposed that the adoption of an alternative technology based on the viral propagation in insect cell cultures could help to overcome the problems associated with in vivo technology and enable the development of well standardized, controlled, and scalable production processes for insecticidal baculoviruses (Szewczyk et al. 2006). In the early part of the twentieth century, entomologists had a dream of utilizing insect cells grown in vitro as a tool for producing entomopathogens. These early experiments used a simple saline solution or hemolymph as the culture medium, and cultures could rarely be kept for more than a few days. A breakthrough occurred four decades ago when Grace (1962) successfully established long-term cultures of insect cells. Since then, over 500 continuous cell lines have been established from over 100 insect species (Lynn 1999). Insect pathologists have cells capable of replicating dozens of insect-specific viruses (Granados and McKenna 1995), while plant pathologists and vertebrate pathologists have cells capable of replicating viruses transmitted by insects (Mitsuhashi 1989). Mass production of the virus at reasonable costs is an important factor in the development of NPVs into a marketable product.

\subsubsection{In Vitro Production}

Baculoviruses can be produced in vitro in infected insect cells cultivated in bioreactors. In order to develop an economically feasible process to produce baculoviruses in insect cells, low-cost culture media that satisfy the nutritional demands of both uninfected and infected cells are needed to achieve high virus yields. Fetal calf serum is the most widely used additive in insect cell culture media. However, its high cost and batch-to-batch variability are the drawbacks in its utilization to sustain baculovirus production in large-scale processes. Therefore, a replacement for the fetal calf serum in insect cell culture media is the key step to develop a technically and economically feasible process to produce baculoviruses in vitro. Recent studies demonstrated that insect's cells are able to both proliferate permanently and replicate baculovirus in a lipid-free environment. However, in order to obtain a useful medium for technological applications, it will be necessary to optimize the composition of the multiple supplements and evaluate its performance in a lipid-supplemented environment. Insect cell cultures have been extensively utilized by Linda and Lua Steven Reid (2003) for means of production for heterologous proteins and bio-pesticides. Spodoptera frugiperda (Sf9) and T. ni (High Five ${ }^{\mathrm{TM}}$ ) cell lines have been widely used for the production of recombinant 
proteins; thus, metabolism of these cell lines has been investigated thoroughly over the recent years. NPV isolated from the alfalfa looper, A. californica, was replicated successfully and rapidly in a suspended ovarian cell line of the cabbage looper, $T . n i$ (Vail and Jay 1973). Polyhedra were observed in the nucleus of cells within $20 \mathrm{~h}$ after inoculation. The cyto-pathological changes typical of nuclear polyhedrosis infections were observed, and an average of 64 polyhedra/cell was produced. These polyhedra were quantitatively as infectious to cabbage looper larvae as those produced in vivo. In addition, they were infective to $H$. virescens, Pectinophora gossypiella, S. exigua, A. californica, and A. falcifera. Bioassays have indicated that both $H$. zea and $H$. armigera viruses produced in vitro maintain biological activity (Suzanne 2009 and Szewczyk et al. 2006). Chakraborty et al. (1999) studied the in vitro production of virus from $H$. armigera (HaSNPV) and its possible use as a specific Helicoverpa/Heliothis larvicide. Growth kinetics of $H$. zea cells and virus OB yields were compared in three SF900II-based media, namely, SF900II (serumfree), SF900II $+1 \%$ serum, or SF900II $+10 \%$ serum. Viable cell densities were usually higher in the media supplemented with serum than in the serum-free medium; however, in the serum-free medium, cell diameters were 1.7 times greater (i.e., individual cell volumes were five times larger). Four new cell lines, designated as NTU-LY-1 to 4, respectively, were established from the pupal tissues of Lymantria xylina Swinhoe (Lepidoptera: Lymantriidae) (Wu and Wang 2006). These cell lines have been cultured approximately 80 passages during 2 years in TNM-FH medium supplemented with $8 \%$ fetal bovine serum, at a constant temperature of $28{ }^{\circ} \mathrm{C}$. Each line consists of three major morphological types: round cells, spindle-shaped cells, and giant cells.

Sundeep et al. (2005) developed two cell lines from the larval hemocyte and embryonic tissue of $H$. armigera and designated them as NIV-HA-1195 and NIV-HA-197, respectively. The NIV-HA-197 cell lines were found highly susceptible to HaSNPV, yielding a very high titer $\left(2.88 \times 10^{7} \mathrm{NPV} / \mathrm{ml}\right)$ on the 10th postinfection day (PID). The HaSNPV OBs produced in vitro were highly virulent to the second and third instars $H$. armigera larvae causing cessation of feeding on the 2nd day and mortality in 6 days. This cell line is also found to be growing well in goat serum (GS)-supplemented medium producing a comparable yield of OBs. Goat serum, being cheap and locally available, will help in the large-scale production of HaSNPV for use as a biopesticide in the future. The cell line NIV-HA-197 was found to be susceptible to the baculoviruses AcMNPV, SIMNPV, and HaSNPV (Sundeep et al. 2002). More than $90 \%$ of the cells were infected by HaSNPV on the seventh PID, and $28.8 \times 10^{6} \mathrm{NPV} / \mathrm{ml}$ was yielded on the 10th PID. The in vitrogrown HaSNPV caused $100 \%$ mortality, when fed to the second instar $H$. armigera larvae, in 6 days. Isoenzyme profile and results of $16 \mathrm{~S}$ rRNA heteroduplex analysis clearly indicated the species specificity of the new cell line NIV-HA-1195 (Sundeep et al. 2002) and was also found susceptible to the baculoviruses, $A c \mathrm{NPV}$, SlNPV, and the homologous HaNPV. Pant et al. (2002) reported that the $H$. armigera cell line from the embryonic tissue was highly susceptible to $\mathrm{HaNPV}$ $\left(6.3 \times 10^{6} \mathrm{NPV} / \mathrm{ml}\right)$. These in vitro-grown $\mathrm{HaNPV}$ s caused $100 \%$ mortality in the second instar larvae. The cultures could grow as suspension culture on shakers and 
may find application for the in vitro production of wild-type/recombinant baculoviruses as bio-insecticides.

Nakat (2004, In vitro production of nuclear polyhedrosis virus of Helicoverpa armigera and Spodoptera litura and its field efficacy in Western Maharashtra. Department of Entomology, Mahatma Phule Krishi Vidyapeeth, Rahuri, Maharashtra, unpublished) standardized the procedure for monolayer and spinner culture of $S f-9, S f-21$, and $\mathrm{Ha}-197$ cells. The growth curve of different cells in spinner culture was plotted on the basis of daily viable cell count. The cell line $S f-9$ was susceptible for both the baculoviruses AcMNPV and SlNPV in monolayer. The cell line $\mathrm{Ha}-197$ was found susceptible for $\mathrm{HaNPV}$ in monolayer. For production of $\mathrm{HaNPV}, \mathrm{Ha}$ 197 cell line with $\mathrm{HaNPV}$ wild-type MPKV strain was found to be efficient, more virulent, and infectious in both the cell lines. The procedure for the cell lysis was standardized to extract the POBs from infected cells with the addition of $0.1 \%$ SDS and deep freezing at $-20{ }^{\circ} \mathrm{C}$ followed by 15 min sonication resulting in good separations of POBs from 80 to $90 \%$ infected cells. The field demonstrations of in vitro- and in vivo-produced SINPV and $H a \mathrm{NPV}$ were conducted on capsicum, gerbera, rose, soybean, and chickpea. The effectiveness of in vitro-produced NPVs was found to be superior, causing larval mortality in the range of 78-100\% as compared to in vivo-produced virus which was 70-88\%.

The insect cell line, the culture medium, the bioreactor, the virus, the infection parameters, and the culture strategy are elements of the insect cell culture technology that must be optimized in order to develop in vitro production processes for insecticidal baculoviruses (Claus Juan et al. 2012). The cell line $H z$-AM1 has been used widely to examine possible factors affecting the yields and the potency of $H a \mathrm{NPV}$. These factors include the medium, supplemented serum, cell density at infection, multiplicity of infection, viral strain, and passage effect (Chakraborty et al. 1996; Lua and Reid 2000; Ogemo et al. 2007). Increasing OB yields per cell in culture is the main challenge to enable commercialization of in vitro production of NPVs. Isolating clones from a heterogeneous cell population may allow development of a high virus-producing cell clone. An automated robotic clone-picking system to establish over 250 insect clones of an $H$. zea cell population to be screened for virus production has been carried out by Nguyen et al. 2011. The type and degree of passage effect are dependent on the cell lines and the virus species (Krell 1996). Homologous cell lines are desirable for the production of an NPV, whereas heterologous NPV infection of cell lines decreases the productivity and yields less virulent progeny viruses (Tompkins et al. 1988).

Although the production of insecticidal baculoviruses in insect cell cultures has been proposed as an alternative to overcome the limitations of the in vivo processes, so far no in vitro process could be even implemented on an industrial scale and baculovirus occlusion bodies are still produced in infected insect larvae (Claus Juan et al. 2012). Some factors that 25 years ago have hindered the development of largescale production processes for baculoviruses in insect cell cultures, such as the sensitivity of insect cells to the stresses linked to the mechanical agitation in stirred tank reactors and to the bubble rupture in sparged bioreactors, have been resolved, 
and several cell lines can be cultivated today in industrial bioreactors of large volume to produce occlusion bodies or recombinant proteins.

In vitro propagation in susceptible insect cell lines is the best option for the commercial production of this virus. Recently, NIV (Pune) developed indigenous cell lines from four insect species, and their susceptibility to different NPVs was tested, and are commercially selling them to interested scientists (Pant et al. 2002). The cultures can grow as suspension culture on shakers and are found to be successful for in vitro production of wild-type/recombinant baculoviruses as bio-insecticides. However, most cell lines have not been sufficiently characterized with respect to certain issues such as (1) simplification of the composition of the culture medium, (2) possibility to obtain high volumetric yields of viral OBs, and (3) optimization of seed virus or budded virus or nonoccluded virus. Production related to economic feasibilities for entrepreneurs needs to be addressed.

\subsection{Diagnostic and Quality Control Tests}

The reliability of the product is crucial in ensuring acceptance and sustained use by the farmers. The issue of erratic performance of viral biocontrol agents has been recognized as a significant factor in limited successful commercialization (Lisansky 1997). It has been widely perceived that viral agents have not achieved a level of efficacy comparable with that of chemicals or other bio-pesticides such as Bacillus thuringiensis (Berliner).

Mass production of NPV insecticide is simple and widely produced even at farmer level. Although commercial production, quality, and storage were still contentious issues, NPV is multiplied on field-collected larvae and being applied on crops. Multiplying NPV on field-collected larvae was found to be easier and cost-effective compared to laboratory-reared larvae, but efficacy and quality of which may be affected due to contaminants such as bacteria and fungi.

The effectiveness of the viral insecticide is critically dependent on the concentration of POB, which is expressed as LE. Generally, a standard stock preparation consists of $1 \mathrm{LE}$, i.e., $6 \times 10^{9} \mathrm{POB} / \mathrm{ml}$. NPV production methods have been well established in many developing countries. Appropriate, sensitive, and reliable serological tools (Kohler and Milstein 1975; Kelly et al. 1978; Towbin et al. 1979; Crook and Payne 1980; Smith and Summers 1981; Zhang and Kaupp 1988; Lu et al. 1995) are not available at this stage and will go a long way in the quality control of insect viruses in developing countries. Once developed, the tools would be of immense value to public and private entrepreneurs, such as state bio-pesticide production laboratories and regulatory agencies. In addition to this, the highly standardized, accurate, and sensitive diagnostic tools for NPV detection in field-collected larvae would be beneficial to pest management personnel, because early detection of NPV disease could make it possible to predict the occurrence of an imminent epizootic and thus alter the pest control tactics to be employed (Volkman and Falcon 1982). 
As part of quality control during mass production of NPVs used for commercial viral insecticide preparations at ICRISAT, polyclonal antibodies were raised against purified polyhedrin (POB) protein preparations and used these antibodies to develop ELISA and Western blotting assays to detect NPVs. The sensitivity of the ELISA was $15 \mathrm{ng} / \mathrm{ml}$ of semi-purified viral protein or $30 \mathrm{ng} / \mathrm{ml}$ POBs from the NPV infected larval extracts. These antibodies are useful to diagnose the early stages of larval infection by NPV and also for the quantification of the NPVs during production of viral insecticides for $\mathrm{HaNPV}$, SlNPV, and AmalNPV (Sridhar Kumar et al. 2007). For qualitative detection of NPVs in larval homogenates, Western immunoblotting and indirect immunofluorescence assay, and for quantitative detection direct antigen coating (DAC) and indirect competitive (IC)-ELISA tools were developed and evaluated (Sridhar Kumar 2008). Since, polyhedrin is the major component of NPV polyhedra, is coded by the virus, and its presence in larvae indicates the presence of NPV or an NPV infection. Similarly, the relationship between three NPVs isolated from the larvae of H. armigera, S. exigua, and S. litura in Taiwan was determined by assaying the polyhedrin in DAC-ELISA with polyhedrin polyclonal antisera specific to each polyhedrin (Tuan et al. 1999), and similarly, a monoclonal antibody-based DAC-ELISA was developed for the identification and differentiation of OpMNPV and OpSNPV and also for detection of their homologous polyhedrin in larval extracts with sensitivity of $100 \mathrm{ng} / \mathrm{ml}$ in the presence of host tissue extract, rather than $5 \mathrm{ng} / \mathrm{ml}$ in its absence (Quant et al. 1984). However, competition between insect and viral proteins for binding to ELISA plate surface has reduced the detection sensitivity of the DAC-ELISA, particularly when crude insect extracts were used. Since it was found that host tissue extract interfered with the assay, still we were able to determine its absolute sensitivity in the presence of unknown quantities of host tissue extract. To eliminate the competition between insect and viral proteins for binding sites in the ELISA plate surface in DAC-ELISA, we attempted to avoid the interference phenomenon by standardizing an IC-ELISA to estimate the polyhedrin content in insect extracts. Similarly, an IC-ELISA was standardized to evaluate the bio-safety of recombinant and wildtype NPV of A. californica (Ashour et al. 2007). Similarly, Crook and Payne (1980) examined the direct, indirect, and double antibody sandwich methods of ELISA for their ability to detect and discriminate between granulosis viruses from Pieris brassicae, Agrotis segetum, and $C$. pomonella and for their specificity in the presence of host material, and they concluded that the indirect method was the most sensitive and capable of detecting down to about $1 \mathrm{ng}$ of dissolved capsules $/ \mathrm{ml}$ compared with $10 \mathrm{ng} / \mathrm{ml}$ for the double antibody sandwich method and $25 \mathrm{ng} / \mathrm{ml}$ for the direct method and the double antibody sandwich method was more specific and showed greatest discrimination between different granulosis viruses.

Also the DAC and IC-ELISA tools were evaluated for their performance in quantification of POBs in commercial NPV preparations. The number of POBs present in the sample bottle was determined by extracting the total polyhedrin and compared with the standard regression graph of polyhedrin extracted from known number (estimated by microscopic counting) of POB standards such as $6 \times 10^{9}$ to $2.34 \times 10^{7} \mathrm{POB} / \mathrm{ml}$ ( $1 \mathrm{LE}$ to $\left.0.0078 \mathrm{LE}\right)$. These ELISA methods are sensitive to a 
minimum of approximately $4.6875 \times 10^{7} \mathrm{POBs} / \mathrm{ml}(0.015 \mathrm{LE} / \mathrm{ml})$, which is little bit higher to the range (100-2,000) of previous reports (Crook and Payne 1980; Kelly et al. 1978; Longworth and Carey 1980; Shamim et al. 1994). The ELISA methods can be used to quantify infection, unlike other methods, and this feature may be applied to predict the potential inoculum required for future populations. Previously, it has been shown that the ELISA method can be used to quantify baculoviruses (Clark and Barbara 1987). Tuan et al. (1998) compared the visual counting of POBs by microscope, bioassay, SDS-PAGE, and ELISA for quality control of SINPV products, and ELISA has proved to be better than SDS-PAGE. The ELISA results were comparable to light microscope counting of POBs (Sridhar Kumar 2008). The absorbance values suggest that the ELISA method can be used to accurately quantify virus POBs and virus infections from tissue homogenates. Recently, Thorne et al. (2007) reported that the alkali-treated POB lysates were assayed in IC-ELISA for estimation of total POBs in semi-purified commercial NPV samples or in insect tissue extracts with a sensitivity of minimum of approximately 850 POBs. Similarly, Parola et al. (2003) reported the estimation of granulin in commercial GV suspensions of Epinotia aporema GV by DAS-ELISA with a sensitivity of $0.53 \mathrm{ng} / \mathrm{ml}$ of purified OB suspensions; this represented $2.0 \times 10^{4} \mathrm{OBs} / \mathrm{ml}$.

These diagnostic and quality control tests are convenient for routine detection and quantification of NPVs, and this technology will also be transferred to the bio-products agribusiness units for commercialization of NPV production. Also the ELISA and Western immunoblot assays can be successfully applied in bioassay experiments during optimization of conditions for the productivity and quality of NPVs to get the maximum virus yield as well as to reduce the development of bacterial contamination. In addition to this application of ELISA tools at field level, evaluation of the efficacy of NPVs is useful for ecological and epidemiological studies of NPVs during IPM programs and also during the surveys of their persistence and outbreaks of natural epizootics in the environment.

\subsection{Way Forward}

- Over the past 25 years, the research approach on NPVs has evolved toward being more ecologically holistic with industry's concerns.

- Although viral pesticides still represent a very small portion of plant protection at present, their role was considered significant.

- Though NPVs gained prominence as environmentally friendly alternatives to chemical insecticides, they still face a number of hurdles in their production, marketing, and utilization.

- Importance of effective multidisciplinary research, public, private, people partnerships.

- Need for in-depth knowledge among farmers, extension, and policy makers about bio-pesticides. 
- Lack of effective regulations can lead to poor product quality, performance, and loss of user confidence.

- NPVs that can perform effectively in wider environments and larger host range have immense potential.

- Prioritize research for better integration of bio-agents into production systems, such as in rotating these with chemical pesticides and developing these into effective bio-models.

\section{References}

Abul-Nasr S, Elnagar S (1980) The susceptibility of the cotton leafworm, Spodoptera littoralis (Boisd) to different isolates of nuclear polyhedrosis virus. J Appl Entomol 90:289-292

Aizawa K (1963) The nature of infections caused by nuclear polyhedrosis viruses. In: Steinhaus EA (ed) Insect pathology: an advanced treatise, vol 1. Academic, New York, pp 381-412

Anderson RF, Shieh TR, Huang HT, Rogoff MH (1972) Production of a viral pesticide. Proc Symp Fermentat Technol Today 2:493-505

Angelini A, Labonne V (1970) A technique for the rearing of Heliothis armigera (Hub.) and a possibility of producing a nuclear virus disease in the Ivory Coast. Cotton Fibres Tropicales 25:501-504

Anon (2009) Biopesticides market to reach $\$ 1$ billion in 2010. http://www.ien.com/article/ biopesticides-market-to/8648

Arguad O, Croizier L, Lopez-Ferber M, Croizier G (1998) Two key mutations in the host-range specificity domain of the p143 gene of Autographa californica nucleopolyhedrovirus are required to kill Bombyx mori larvae. J Gen Virol 79:931-935

Armes NJ, Jadhav DR, Bond GS, King ABS (1992) Insecticide resistance in Helicoverpa armigera in South India. Pestic Sci 34:355-364

Arora R, Battu GS, Bath DS (1997) Comparative evaluation of some native isolates of a nuclear polyhedrosis virus against Heliothis armigera (Hübner). J Entomol Res 21:183-186

Ashour MB, Ragheb DA, EI-Sheikh EI-Sayed A, Gomaa EI-Adarosy A, Kamita Shizuo G, Hammock Bruce D (2007) Biosafety of recombinant and wild type nucleopolyhedrovirus as bioinsecticides. Environ Res Public Health 4:111-125

Attathom T, Chaeychomsri S, Mahattana C, Siriwattanagul W (1990) Technological development for the local production of nuclear virus of Helicoverpa armigera. In: Proceedings on $\mathrm{V}$ international colloquium on invertebrate pathology and microbial control, Adelaide, 2024 August 1990

Backwad DG (1979) Studies on NPV infection in Heliothis armigera (Hubner) and Anomis sabulifera. M.Sc. (Ag.) Thesis, Marathwada Agriculture University, Parbhani, p 141

Banowetz GM, Fryer JL, Iwai PJ, Martignoni ME (1976) Effects of the douglas-fir tussock moth nucleopolyhedrosis virus (baculovirus) on three species of salmonid fish. Forest Service Research Paper PNW-214. U.S. Department of Agriculture, Washington, DC

Bansal OB, Bansal A, Behera AK, Das RH, Kumar M (1997) Characterization of the polyhedron gene of Spodoptera litura nuclear polyhedrosis virus. Virus Genes 14:175-180

Battu GS (1990) Yield levels of the occlusion bodies obtained from the Baculovirus infected Hellula undalis (Fabricius). Ind J Entomol 51:317-325

Battu GS (1992) Potential use of baculoviruses on Lepidopteran pests in Punjab. In: Ananthakrishnan TN (ed) Emerging trends in biological control of phytophagous insects. Oxford and IBH Company Private Ltd., New Delhi, pp 174-181

Battu GS, Ramakrishna N (1987) Investigations on the nuclear polyhedrosis virus of Diacrisia oblique (Walker): bioassay of viral activity. Entomon 12:81-84 
Bell MR (1991) Effectiveness of microbial control of Heliothis spp. on early season wild geraniums. Field and field cage tests. J Econ Entomol 84:851-854

Bellotti AC (1999) Recent advances in cassava pest management. Annu Rev Entomol 44:345-370

Benz GA (1986) Introduction: historical perspective. In: Granados RR, Federici BA (eds) The biology of baculoviruses. CRC, Boca Raton, pp 1-35

Bergold GH (1947) Die Isolierung des Polyeder Virus und die Natur der Polyeder. Z Naturforsch 2B:122-143

Bergold GH (1948) Uber die Kapsel virus-krankheit. Z Naturforsch 3B:338-342

Bergold GH (1982) The nature of the nuclear polyhedrosis viruses. Biol Baculoviruses 413-453

Biji CP, Sudheendrakumar VV, Sajeev TV (2006) Influence of virus inoculation method and host larval age on productivity of the nucleopolyhedrovirus of the teak defoliator, Hyblaea puera (Cramer). J Virol Methods 133:100-104

Blissard GW, Rohrmann GF (1990) Baculovirus diversity and molecular biology. Annu Rev Entomol 35:127-155

Blissard GW, Black B, Crook N, Keddie BA et al (2000) Family Baculoviridae. In: Van Regenmortel MHV et al (eds) Virus taxonomy: seventh report of the International Committee on Taxonomy of Viruses. Academic, San Diego, pp 195-202

Braunagel SC, Russell WK, Rosas Acosta G, Russell DH, Summers MD (2003) Determination of protein composition of the occlusion-derived virus of Autographa californica nucleopolyhedrovirus. Proc Natl Acad Sci USA 100:9797-9802

Brown SE, Maruniak JE, Knudson DL (1984) Physical map of SeMNPV baculovirus DNA: an AcMNPV genomic variant. Virology 136:235-240

Bulach DM, Kumar CA, Zaia A, Liang BF, Tribe DE (1999) Group-II nucleopolyhedrovirus subgroups revealed by phylogenetic analysis of polyhedrin and DNA polymerase gene sequences. J Invertebr Pathol 73:59-73

Burges HD (1981) Microbial control of pests and plant diseases, 1970-1980. Academic, New York, p 949

Burges HD, Thompson EM (1971) Standardisation and assay of microbial insecticides. In: Burges HD, Hussey NW (eds) Microbial control of insects and mites. Academic, London, pp 591-622

Caballero P, Aldebis HK, Vargas-Osuna E, Santiago-Alvarez C (1992) Epizootics caused by a nuclear polyhedrosis virus (NPV) in populations of Spodoptera exigua in Southern Spain. Bio Sci Technol 2:45-149

Carter JB (1984) Viruses as pest control agents. Biotechnol Gen Eng Rev 1:375-405

Chakraborthy S, Monsour C, Teakle R, Reid S (1999) Yield, biological activity, and field performance of a wild-type Helicoverpa Nucleopolyhedrovirus produced in $\mathrm{H}$. zea cell cultures. J Invertebr Pathol 73:199-205

Chakraborty S, Green Field P, Reid S (1996) In-vitro production studies with a wild type Helicoverpa baculovirus. Cytotechnology 22:217-224

Christian PD, Gibb N, Kasprzak AB, Richards A (2001) A rapid method for the identification and differentiation of Helicoverpa nucleopolyhedroviruses (NPV Baculoviridae) isolated from the environment. J Virol Methods 96:51-65

Clark M, Barbara D (1987) A method for quantitative analysis of ELISA data. J Virol Methods $15: 213-222$

Claus Juan D, Gioria Verónica V, Micheloud Gabriela A et al (2012) Production of insecticidal baculoviruses in insect cell cultures: potential and limitations. In: Soloneski S (ed) Insecticides - basic and other applications. In Tech. Available from: http://www.intechopen.com/books/ insecticides

Croizier G, Ribeiro HCP (1992) Recombination as a possible major cause of genetic heterogeneity in Anticarsia gemmatalis nuclear polyhedrosis virus populations. Virus Res 26:183-196

Crook NE, Payne CC (1980) Comparison of three methods of ELISA for baculoviruses. J GenVirol 46:29-37

David WAL, Gardiner BOC (1966) Persistence of a granulosis virus of Pieris brassicae on cabbage leaves. J Invertebr Pathol 8:180-183 
David WAI, Gardiner BOC (1967a) The effect of heat, cold, and prolonged storage on a granulosis virus of Pieris brassicae. J Invertebr Pathol 9:555-562

David WAL, Gardiner BOC (1967b) The persistence of a granulosis virus of Pieris brassicae in soil and in sand. J Invertebr Pathol 9:342-347

David WAL, Ellaby SV, Taylor G (1971) The stability of a purified granulosis virus of the European cabbageworm, Pieris brassicae, in dry deposits of intact capsules. J Invertebr Pathol 17:228-233

De Moraes RR, Maruniak JE (1997) Detection and identification of multiple baculoviruses using the polymerase chain reaction (PCR) and restriction endonuclease analysis. J Virol Methods 63:209-217

Doyle CJ, Hirst ML, Cory JS, Entwistle PF (1990) Risk assessment studies: detailed host range testing of wild-type cabbage moth, Mamestra brassicae (Lepidoptera: Noctuidae) nuclear polyhedrosis virus. Appl Environ Microbiol 56:2704-2710

Ebora RV, Shepard BM, Cadapan EP (1990) Mass propagation and factors affecting virulence of a nuclear polyhedrosis virus of Spodoptera litura (Fab.). Philippine J Biotechnol 2:138-148

Falcon LA (1971) Microbial control as a tool in integrated control programs. In: Huffaker CB (ed) Biological control. Plenum, New York, pp 346-364

Fauquet CM, Mayo MA, Maniloff J, Desselberger U, Ball LA (eds) (2004) Virus taxonomy. VII report of the ICTV. Elsevier/Academic, London, p 1258

Federici BA (1978) Baculovirus epizootic in a larval population of the clover cutworm, Scotogramma trifolii, in Southern California. Environ Entomol 7:423-427

Federici BA (1997) Baculovirus Pathogenesis. In: Miller LK (ed) The baculoviruses. Plenum, New York, pp 33-59

Federici BA, Hice RH (1997) Organization and molecular characterization of genes in the polyhedrin region of the Anagrapha falcifera multinucleocapsid NPV. Arch Virol 142:333348

Figueiredo E, Munoz D, Escribano A, Mexia A, Vlak J, Caballero P (1999) Biochemical identification and comparative insecticidal activity of nucleopolyhedrovirus isolates pathogenic for Heliothis armigera larvae. J Appl Entomol 123:1-00

Funk CJ, Braunagel SC, Rohrmann GF (1997) Baculovirus structure. In: Miller LK (ed) The baculoviruses. Plenum, New York, pp 7-32

Geetha N, Rabindra RJ (1999) Genetic variability and comparative virulence of some geographic isolates of nuclear polyhedrosis virus of Helicoverpa armigera Hub. In: Ignacimuthu S, Sen A, Janarthana S (eds) Biotechnological application for integrated pest management. Oxford and IBH Publ. Co. Pvt. Ltd., New Delhi, pp 65-78

Gelernter WD, Federici BA (1990) Virus epizootics in California populations of Spodoptera exigua: dominance of a single genotype. Biochem Syst Ecol 18:461-466

Gopali JB, Lingappa S (2001a) Refinement of technique for mass production of virus from Helicoverpa armigera (Hubner). Karnataka J Agric Sci 14:947-954

Gopali JB, Lingappa S (2001b) Evaluation of safety period for field use of virus (HaNPV) under different set of storage conditions. Karnataka J Agric Sci 14:1072-1074

Grace TD (1962) Establishment of four strains of cells from insect tissues grown in vitro. Nature 195:788-789

Granados RR, McKenna KA (1995) Insect cell culture methods and their use in virus research. In: Wood HA, Granados RR, Schuler ML et al (eds) Baculovirus expression systems and biopesticides. Wiley-Liss, New York, pp 13-39

Groner A (1986) Specificity and safety of baculoviruses. In: Granados RR, Federici BA (eds) The biology of baculoviruses, biological properties and molecular biology, vol I. CRC, Boca Raton, pp 177-202

Grzywacz D, McKinley D, Jones KA et al (1997) Microbial contamination in Spodoptera littoralis nuclear polyhedrosis virus produced in insects in Egypt. J Invertebr Pathol 69:151-156 
Gudauskas RT, Cannerday D (1968) The effect of heat, buffer salt and H-ion concentration, and ultraviolet light on the infectivity of Heliothis and Trichoplusia nuclear polyhedrosis viruses. J Invertebr Pathol 12:405-411

Guo ZJ, Ge JQ, Wang D, Shao YM, Tang QY, Zang CX (2006) Biological comparison of two genotypes of Helicoverpa armigera single-nucleocapsid nucleopolyhedrovirus. BioControl. doi:10.1007/s1056-006-9008-6

Gupta RK, Raina JC, Monobrullah MD (2007) Optimization of In vivo production of nucleopolyhedrovirus in homologous host larvae of Helicoverpa armigera. J Entomol 4:279-288

Gupta RK, Raina JC, Arora RK, Bal K (2010) Selection and field effectiveness of nucleopolyhedrovirus isolates against Helicoverpa armigera (Hubner). Int J Virol 6:164-178

Harrap KA, Payne CC, Robertson JS (1977) The properties of three baculoviruses from closely related hosts. Virology 79:14-31

Harris JG (1997) Microbial insecticides, an industry perspective in microbial insecticides: novelty or necessity? Br Crop Protect Council Proc Monograph Ser 68:41-50

Harrison RL, Bonning BC (1999) The nucleopolyhedroviruses of Rachiplusia ou and Anagrapha falcifera are isolates of the same virus. J Gen Virol 80:2793-2798

Hedlund RC, Yendol WG (1974) Gypsy moth nuclear polyhedrosis virus production as related to inoculating time, dosage and larval weight. J Econ Entomol 67:61-63

Herniou EA, Olszewski JA, Cory JS, O' Reilly DR (2003) The genome sequence and evolution of baculoviruses. Annu Rev Entomol 48:211-234

Hink WF (1982) Production of Autographa californica nuclear polyhedrosis virus in cells from large scale suspension cultures. In: Kurstak E (ed) Microbial and viral pesticides. Marcel Dekker, New York, pp 493-506

Hooft van Iddekinge BJK, Smith GE, Summers MD (1983) Nucleotide sequence of polyhedrin gene of Autographa californica nuclear polyhedrosis virus. Virology 131:5561-5565

Hostetter DL, Puttler B (1991) A new broad host spectrum nuclear polyhedrosis virus isolated from a celery looper, Anagrapha falcifera (Kirby), (Lepidoptera: Noctuidae). Environ Entomol 20:1480-1488

Huber J (1985) Progress in the production of codling moth granulosis virus: comparison of several virus preparations. In: Production and application of biopesticides on a viral basis in orchards and vegetables. Expert meeting, Manfauet, 5-7 July 1985. Commission of European communities, General Directorate Agriculture

Huber J, Krieg A (1978) Studies with baculoviruses on mammals. Z Angew Zool 65:69-80

Hughes PR, Getting RR, McCarthy WJ (1983) Comparison of the time mortality response of Heliothis zea to 14 isolates of Heliothis nuclear polyhedrosis virus. J Invertebr Pathol 41:256261

Hunter DK, Collier SJ, Hoffman DF (1975) Compatibility of malathion and the granulosis virus of the Indian meal moth. J Invertebr Pathol 25:389-390

Hunter-Fujita RF, Entwistle PF, Evans FH, Crook NE (1998) Insect virus and pest management. Wiley, Chichester, p 620

Ignoffo CM (1965) The nuclear polyhedrosis virus of Heliothis zea (Boddie) and Heliothis virescens (Fabricius) I-virus propagation and its virulence. J Invertebr Pathol 7:209-216

Ignoffo CM (1966a) Insect viruses. In: Smith CN (ed) Insect colonization and mass production. Academic, New York, pp 501-530

Ignoffo CM (1966b) Standardization of products containing insect viruses. J Invertebr Pathol 48:547-548

Ignoffo CM (1973) Effects of entomopathogens on vertebrates. Ann NY Acad Sci 217:141-172

Ignoffo CM, Boeing OP (1970) Compartmental disposable trays for rearing insects. J Econ Entomol 63:1696-1697

Ignoffo CM, Couch TL (1981) The nuclear polyhedrosis virus of Heliothis species as a microbial insecticide. In: Burges HD (ed) Microbial control of pests and plant diseases 1970-1980. Academic, London pp, pp 329-362 
Ignoffo CM, Rafajko RR (1972) In vitro attempts to infect primate cells with the nucleopolyhedrosis virus of Heliothis. J Invertebr Pathol 20:321-325

Ignoffo CM, Shapiro M (1978) Characteristics of baculovirus preparations processed from living and dead larvae. J Econ Entomol 71:186-188

Injac M (1973) The role of granulosis in regulating the density of population of fall webworm (Hyphantria cunea Drury) in Vojvodina, Yugoslavia. Zast Bilja 24:103-110

Jacques RP, Long DR (1978) Efficacy of mixture of Bacillus thuringiensis, viruses and chlordimeform against insects on cabbage. Can Entomol 110:443-448

Jayaraj S, Sathiah N (1993) Heliothis culture techniques. In: Proceedings of national training on mass multiplication of biocontrol agents, Tamil Nadu Agricultural University, Coimbatore, pp $1-4$

Jehle JA, Fritsch E, Nickel A, Huber J, Backhaus H (1995) TC14.7: a novel Lepidopteran transposon found in Cydia pomonella granulosis virus. Virology 207:369-379

Jun T, Shohei O, Takayoshi I, Madoka N, Yasuhisa K (2007) Productivity and quality of polyhedral occlusion bodies of a nucleopolyhedrovirus harvested from Spodoptera litura (Lepidoptera: Noctuidae) larvae. Appl Entomol Zool 42:21-26

Kambrekar DN, Kulkarni KA, Giraddi RS (2007) Assessment of quality of HaNPV samples produced by private firms. Karnataka J Agric Sci 20:417-419

Kamita SG, Maeda S (1997) Sequencing of the putative DNA helicase-encoding gene of the Bombyx mori nuclear polyhedrosis virus. Gene 190(1):173-9

Katagiri K (1981) Pest control by cytoplasmic polyhedrosis viruses. In: Burges HD (ed) Microbial control of pests and plant diseases 1970-1980. Academic, New York, pp 433-440

Kelly DC, Edwards ML, Evans HF, Robertson JS (1978) The use of the enzyme linked immunosorbent assay to detect a nuclear polyhedrosis virus in Heliothis armigera larvae. J Gen Virol 40:465-469

Kelly DC, Brown DA, Robertson JS, Harrap KA (1980) Biochemical, biophysical and serological properties of two singly enveloped nuclear polyhedrosis viruses from H. armigera and H. zea. Microbiologica 3:319-331

Kern M, Vaagt G (1996) Pesticide quality in developing countries. Pesticide Out Look 7-10

Kohler G, Milstein C (1975) Continuous cultures of fused cells secreting antibodies of predefined specificity. Nature 256:495-497

Kool M, Vonken JW, Van Lier FLJ, Tramper J, Vlak JM (1991) Detection and analysis of Autographa californica nuclear polyhedrosis virus mutants with defective interfering properties. Virology 183:739-746

Kranthi KR, Jadhav DR, Kranthi S, Wanjari RR, Ali SS, Russel DA (2002) Insecticide resistance in five major insect pests of cotton in India. Crop Prot 21:449-460

Krell PJ (1996) Passage effect of virus interaction in insect cells. In: Vlak JM, De Gooigee CD, Tramper J et al (eds) Insect cell culture, fundamentals and applied aspects. Kluwer Academic, A.H. Dordrecht, pp 125-137

Lange M, Wang H, Hu Z, Jehle JA (2004) Towards a molecular identification and classification system of lepidopteran-specific baculoviruses. Virology 325:36-47

Lautenschlager RA, Kircher CH, Podgwaite JD (1977) Effect of nuclear polyhedrosis virus on selected mammalian predators of the gypsy moth. Forest Service Research Paper NE-377. U.S. Department of Agriculture, Washington, pp 9-29

Lee HH, Miller LK (1978) Isolation of genotypic variants of Autographa californica nuclear polyhedrosis virus. J Virol 27:754-767

Linda HL, Lua Steven Reid LS (2003) Growth, viral production and metabolism of a Helicoverpa $z e a$ cell line in serum-free culture. Cytotechnology 42:109-120

Lisansky S (1997) Microbial biopesticides, in microbial insecticides Novelty or Necessity? Br Crop Protect Council Proc Monograph Ser 68:3-10

Longworth JF, Carey GP (1980) The use of an indirect enzyme-linked immunosorbent assay to detect baculovirus in larvae and adults of Oryctes rhinoceros from Tonga. J Gen Virol 47:431438 
Lu ZQ, Hu GG, Chen LF, Yang F, Hang SB, Le YX, Su DM (1995) Use of monoclonal antibodies and ELISA to detect nuclear polyhedrosis virus (NPV) in the larvae of Helicoverpa armigera. Chinese J Biol Control 11:36-39

Lua HL, Reid S (2000) Serial passage of a Helicoverpa armigera nucleopolyhedrosis virus in Helicoverpa zea serum free suspension culture. J Gen Virol 81:2531-2543

Lynn DE (1999) Development of insect cell lines: virus susceptibility and applicability to prawn cell culture. Methods Cell Sci 21:173-181

Ma XC, Xu HJ, Tang MJ, Xiao Q, Hong Q, Zhang CX (2006) Morphological, phylogenetic and biological characteristics of Ectropis oblique single-nucleocapsid nucleopolyhedrovirus. J Microbiol 44:77-82

Maeda S, Mukohara Y, Kondo A (1990) Characteristically distinct isolates of the nuclear polyhedrosis virus from $S$. litura. J Gen Virol 71:2631-2639

Maskos CB, Miltenburger HG (1981) SDS-PAGE comparative studies on the polyhedral and viral polypeptides of the nuclear polyhedrosis viruses of Mamestra brassicae, Autographa californica, and Lymantria-dispar. J Invertebr Pathol 37:174-180

Matthiessen JN, Christian RL, Grace TDC et al (1978) Large scale field propagation and purification of the granulosis virus of potato moth, Phthorimaea operculella (Lep: Gel). Bull Entomol Res 68:385-391

Miller LK, Dawes KP (1978) Restriction endonuclease analysis to distinguish two closely related nuclear polyhedrosis viruses: Autographa californica MNPV and Trichoplusia ni MNPV. Appl Environ Microbiol 35:1206-1210

Mitsuhashi J (1989) Nutritional requirements of insect cells in vitro. In: Mitsuhashi J (ed) Invertebrate cell system applications. CRC, Boca Raton, pp 3-21, ISBN 0849343739

Monobrullah M (2003) Optical brighteners - pathogenicity enhancers of entomopathogenic viruses. Curr Sci 84:640-645

Monobrullah M, Nagata M (1999) Immunity of lepidopteran insects against baculoviruses. J Entomol Res 23:185-194

Monroe JE, McCarthy WJ (1984) Polypeptide analysis of genotypic variants of occluded Heliothis spp. Baculoviruses. J Invertebr Pathol 43:32-40

Moscardi F (1999) Assessment of the application of baculoviruses for control of Lepidoptera. Annu Rev Entomol 44:257-290

Moscardi F, Allen GE, Greene GL (1981) Control of the velvetbean caterpillar by nuclear polyhedrosis virus and insecticides and impact of treatments on the natural incidence of the entomopathogenic fungus Nomuraea rileyi. J Econ Entomol 74:48-485

Munoz D, Castillejo JI, Caballero P (1998) Two naturally occurring deletion mutants are parasitic genotypes in a Spodoptera exigua nucleopolyhedrovirus strain. Appl Environ Microbiol 64:4372-4377

Murillo R, Munoz D, Lipa JJ, Caballero P (2001) Biochemical characterization of three nucleopolyhedrovirus isolates of Spodoptera exigua and Mamestra brassicae. J Appl Entomol 125:267270

Nakai M, Goto C, Kang W, Shikata M, Luque T, Kunimi Y (2003) Genome sequence and organization of a nucleopolyhedrovirus isolated from the smaller tea tortrix, Adoxophyes honmai. Virology 316:171-183

Narayanan K (1979) Studies on the nuclear polyhedrosis virus of gram pod borer, Heliothis armigera (Hubner) (Noctuidae: Lepidoptera). Ph.D. Thesis, Tamil Nadu Agriculture University, Coimbatore, p 204

Narayanan K (1985) Isolation, purification and inoculation of viral pathogens. In: Jayaraj S (ed) Microbial control and pest management. Tamil Nadu Agriculture University, Arul Jothi Printers, Coimbatore, pp 55-59

Nguyen Q, Qi YM, Wu YC et al (2011) In vitro production of Helicoverpa baculovirus biopesticides-automated selection of insect cell clones for manufacturing and systems biology studies. J Virol Methods 175:197-205 
Odak SK, Srivastava DK, Misra VK et al (1984) Preliminary studies on the pathogenicity of Bacillus thuringiensis and nuclear polyhedrosis virus on Heliothis armigera host in the laboratory and in pot experiments. Legume Res 5:13-17

Ogemo JG, Chaeychomsri S, Kamiya K et al (2007) Cloning and comparative characterization of nucleopolyhedrosis viruses isolated from African bollworm, Helicoverpa armigera (Lepidoptera: Noctuidae) in different geographic regions. J Insect Biotechnol Sericol 76:39-49

Pant U, Sudeep AB, Athawale SS, Vipat VC (2002) Baculovirus studies in new, indigenous lepidopteran cell lines. Indian J Exp Biol 40:63-68

Parola AD, Cap AS, Glikmann G, Romanowski V (2003) An immunochemical method for quantification of Epinotia aporema granulovirus (EpapGV). J Virol Methods 112:13-21

Pawar VM, Thombre UT (1992) Prospects of baculovirus in integrated pest management of pulses. In: Ananthkrishnan TN (ed) Emerging trends in biocontrol of phytophagous insects. Oxford and IBH Publishing Company Private Limited, New Delhi, pp 253-258

Podgwaite JD, Bruen RB, Shapiro M (1983) Microorganisms associated with production lots of the nuclear polyhedrosis virus of the gypsy moth, Lymantria dispar. Entomophaga 28:9-16

Possee RD, Rohrmann GF (1997) Baculovirus genome organization and evolution. In: Miller LK (ed) The baculoviruses. Plenum, New York, pp 109-133

Powell JE, Robertson JL (1993) Status of rearing technology for cotton insects. In: King EG, Brown JM (eds) cotton insects and mites: characterization and management. Cotton Foundation, Memphis

Quant RL, Pearson MN, Rohrman GF et al (1984) Production of polyhedrin monoclonal antibodies for distinguishing two Orgyia pseudotsugata baculoviruses. Appl Environ Microbiol 48:732-736

Rabindra RJ (1992) Genetic improvement of baculoviruses. In: Ananthkrishnan TN (ed) Emerging Trends in Biological control of phytophagous insects. Oxford and F B H Publishing Cooperative Private Ltd., New Delhi, pp 183-186

Rabindra RJ, Subramanian TR (1974) Studies on the nuclear polyhedrosis of Heliothis armigera (Hubner). Madras Agric J 60:217-220

Rao GVR (2006) SATrends 64 ICRISAT Publication

Rao GVR, Meher KS (2004) Optimization of In vivo production of Helicoverpa armigera NPV and regulation of malodor associated with the process. Indian J Plant Protect 32:15-18

Rao GVR, Rupela OP, Rameshwar Rao V, Reddy YVR (2007) Role of biopesticides in crop protection: present status and future prospects. Indian J Plant Protect 35:1-9

Reardon R, Podgwaite JP, Zerillo RT (1996) GYPCHECK - the gypsy moth nucleopolyhedrosis virus product. USDA Forest Service Publication FHTET-96-16

Rivkin H, Mor M, Chejanovsky N (1998) Isolation, replication and polyhedrin gene sequence of an Israeli Helicoverpa armigera single nucleopolyhedrovirus. Virus Genes 17:11-19

Roder A, Punter J (1977) Interactions between nuclear polyhedrosis viruses and vertebrate cells. Zentralbl Bakteriol Parasitenkd Infektionskr Hyg Abt 1 Orig Reihe A 239:459-464

Rohrmann GF (1986) Evolution of occluded baculoviruses. In: Granados R, Federici B (eds) The biology of baculoviruses, vol 1. CRC, Boca Raton, pp 203-215

Rohrmann GF (1992) Baculovirus structural proteins. J Gen Virol 73:749-761

Rohrmann GF (1999) Nuclear polyhedrosis viruses. In: Webster RG, Granoff A (eds) Encyclopedia of virology, 2nd edn. Academic, London, pp 146-152

Rollinson WD, Hubbard HB, Lewis FB (1970) Mass rearing of the European pine sawfly for production of the nuclear polyhedrosis virus. J Econ Entomol 63:343-344

Rovesti L, Crook NE, Winstanely D (2000) Biological and biochemical relationships between the nucleopolyhedroviruses of Mamestra brassicae and Heliothis armigera. J Invertebr Pathol 75:2-8

Russell RLQ, Rohrmann GF (1990) A baculovirus polyhedron envelope protein: immuno gold localization in infected cells and mature polyhedra. Virology 174:177-184 
Saxene H, Ahmad R (2005) NPV production, formulation and quality control. In: Saxena H, Rai $\mathrm{AB}$, Ahmed $\mathrm{R}$ et al (eds) Recent advances in Helicoverpa management. Proceedings of the national symposium on Helicoverpa management: a national challenge, IIPR, pp 1-10

Senthil Kumar CM, Sathiah N, Rabindra RJ (2005) Optimizing the time of harvest of nucleopolyhedrovirus infected Spodoptera litura (Fabricius) larvae under In vivo production systems. Curr Sci 88:1682-1684

Shamim M, Baig M, Datta RK, Gupta SK (1994) Development of monoclonal antibody-based sandwich ELISA for the detection of nuclear polyhedra of nuclear polyhedrosis virus infection in Bombyx mori L. J Invertebr Pathol 63:151-156

Shapiro M, Bell RA (1981) Biological activity of Lymantria dispar nucleopolyhedrosis virus from living and virus killed larvae. Ann Entomol Soc Am 74:27-28

Shapiro M, Bell RA (1982) Production of gypsy moth, Lymantria dispar (L.) nucleopolyhedrosis virus, using carrageenans as dietary gelling agents. Ann Entomol Soc Am 75:43-45

Shapiro M, Ignoffo CM (1969) Nuclear polyhedrosis of Heliothis: stability and relative infectivity of virions. J Invertebr Pathol 14:130-134

Shapiro M, Ignoffo CM (1970) Nucleopolyhedrosis of Heliothis: activity of isolates from Heliothis Zea. J Invertebr Pathol 16:107-111

Shapiro M, Robertson JL, Injac MG, Katagiri K, Bell RA (1984) Comparative infectivities of gypsy moth (Lepidoptera: Lymantriidae) nucleopolyhedrosis virus isolates from North America, Europe and Asia. J Econ Entomol 77:153-156

Shapiro M, Robertson JL, Bell RA (1986) Quantitative and qualitative differences in gypsy moth (Lep: Lyman) NPV produced in different - aged larvae. J Econ Entomol 79:1174-1177

Sherman KE (1985) Considerations in the large scale and commercial production of viral insecticides. In: Karl M, Sherman KE (eds) Viral insecticides for biological control. Academic, London, pp 757-797

Shieh TR (1978) Characteristics of a viral pesticide, Elcar. In: Proceedings of international colloquium and invertebrate pathology, pp 91-194

Shieh TR (1989) Industrial production of viral pesticides. Adv Virus Res 36:315-343

Shieh TR, Bohmfalk GT (1980) Production and efficiency of baculoviruses. Biotechnol Bioeng 22:1357-1375

Shim HJ, Roh JY, Choi JY, Li MS, Woo SD, Oh HW, Boo KS, Je Y (2003) Isolation and characterization of a Lymantria dispar multinucleocapsid nucleopolyhedrovirus isolate in Korea. J Microbiol 41:306-311

Sireesha K (2006) Determination of efficacy of different Helicoverpa armigera nucleopolyhedrovirus (HaNPV) strains and standardization of production procedures. Ph.D. Thesis, Department of Entomology, Agricultural College, Bapatla, Acharya N.G. Ranga Agricultural University, Rajendranagar, Hyderabad

Smith IRL, Crook NE (1988) In vivo isolation of baculovirus genotypes. Virology 166:240-244

Smith GE, Summers MD (1978) Analysis of baculovirus genomes with restriction endonucleases. Virology 89:517-527

Smith GE, Summers MD (1979) Restriction maps of five Autographa californica MNPV variants, Trichoplusia ni MNPV, and Galleria mellonella MNPV DNAs with endonucleases SmaI, KpnI, BamHI, SacI and EcoRI. J Virol 30:393-406

Smith GE, Summers MD (1981) Application of a novel radioimmunoassay to identify baculovirus structural proteins that share interspecies antigenic determinants. J Virol 39:125-137

Smith GE, Summers MD (1982) DNA homology among subgroup A, B and C baculoviruses. Virology 123:393-406

Smits PH, Vlak JM (1987) Biological activity of Spodoptera exigua nuclear polyhedrosis virus against S. Exigua larvae. J Invertebr Pathol 51:107-114

Somasekhar S, Jayapragasam M, Rabindra RJ (1993) Characterization of five Indian isolates of the nuclear polyhedrosis virus of $H$. armigera. Phytoparasitica 21:333-337 
Sridhar Kumar Ch (2008) Development and evaluation of diagnostic tools for nucleopolyhedroviruses infecting major lepidopteran pests of legume crops in the semi-arid tropics. Ph.D. Thesis, Department of Biochemistry, Acharya Nagarjuna University, Andhra Pradesh

Sridhar Kumar C, Sireesha K, Ranga Rao GV, Reddy AS, Waliyar F, Rambabu C, Kumar L (2007) Production of polyclonal antibodies for detection of Nucleopolyhedrovirus infecting Helicoverpa armigera. Indian J Plant Protect 35:210-212

Sridhar Kumar C, Ranga Rao GV, Sireesha K, Kumar PL (2011) Isolation and characterization of baculoviruses from three major lepidopteran pests in the semi-arid tropics of India. Indian $\mathrm{J}$ Virol 22:29-36

Stairs GR, Frasor T, Frasor M (1981) Changes in growth and virulence of a nuclear polyhedrosis virus from Choristoneura fumiferana after passage in Trichoplusia ni and Galleria mellonella. J Invertebr Pathol 38:230-235

Sudhakar S, Mathavan S (1999) Viral pesticides for environmental safety (Helicoverpa armigera) Baculovirus Genome analysis) In: Ignacimuthu A (eds) Biopesticides in insect pest management, pp 199-207

Summers MD, Egawa K (1973) Physical and chemical properties of Trichoplusia ni granulosis virus granulin. J Virol 12:1092-1103

Summers MD, Smith GE (1978) Baculovirus structural polypeptides. Virology 84:90-402

Summers MD, Smith GE, Knell JD, Burand JP (1980) Physical maps of Autographa californica and Rachiplusia ou nuclear polyhedrosis virus recombinants. J Virol 34:693-703

Sun XL, Peng H (2007) Recent advances in biological pest insects by using viruses in China. Virol Sin 22:158-162

Sundeep AB, Shouche YS, Mourya DT et al (2002) New Helicoverpa armigera Hbn cell line from larval hemocyte for baculovirus studies. Indian J Exp Biol 40:69-73

Sundeep AB, Mourya DT, Mishra AC (2005) Insect cell culture in research: Indian scenario. Indian J Med Res 121:725-738

Suzanne MT (2009) Baculovirus genes affecting host function. In Vitro Cell Dev Biol Anim 45:111-126

Szewczyk B, Hoyos-Carvajal L, Paluszek M et al (2006) Baculoviruses: re-emerging biopesticides. Biotechnol Adv 24:143-160

Tanada Y, Kaya H (eds) (1993) Insect pathology. Academic, San Diego

Taun SJ, Tang LC, Hou RF (1989) Factors effecting Pathogenicity of NPV preparations to the corn earworm, Heliothis armigera (Hubner). Entamophaga 34:541-549

Teakle RE, Byrne VS (1989) Nuclear polyhedrosis virus production in $H$. armigera infected at different larval ages. J Invertebr Pathol 53:21-24

Teakle RE, Jensen JM, Giles JE (1985) Susceptibility of $H$. armigera to a commercial nuclear polyhedrosis virus. J Invertebr Pathol 46:166-173

Thomas ED (1975) Normal virus levels and virus levels added for control. In: Summers M, Engler R, Falcon LA, Vail P (eds) Baculoviruses for insect pest control: safety considerations. Am Soc Microbiol, Washington, pp 87-89

Thorne CM, Otvos IS, Conder N, Levin DB (2007) Development and evaluation of methods to detect the Choristoneura fumiferana nuclear polyhedrosis virus. Chinese J Virol 4:61-64

Tompkins GJ, Daugherty EM, Adams JR, Diggs D (1988) Changes in the virulence of nuclear polyhedrosis virus when propagated in alternate Noctuid (Lepidoptera: Noctuidae) cell lines and hosts. J Econ Entomol 81:1027-1032

Towbin H, Staehlin T, Gordon J (1979) Electrophoretic transfer of proteins from polyacrylamide gels to nitrocellulose sheets: procedure and some applications. Proc Natl Acad Sci U S A 76:4350-4354

Tuan SJ, Chen WL, Kao SS (1998) In vivo mass production and control efficacy of Spodoptera litura (Lepidoptera: Noctuidae) nucleopolyhedrovirus. Chinese J Entomol 18:101-116

Tuan SJ, Kao SS, Cheng DJ, Hou RF, Chao YC (1999) Comparison of the characterization and pathogenesis of three lepidopteran nucleopolyhedroviruses (HearNPV, SpeiNPV and SpltNPV) isolated from Taiwan. Chinese J Entmol 19:167-186 
Vail PV, Jay DL (1973) Replication and infectivity of the nuclear polyhedrosis virus of the alfalfa looper, Autographa californica, produced in cells grown in vitro. J Invertebr Pathol 22:231237

Van Lent JWM, Groenen JTM, Klinge-Roode EC et al (1990) Localization of the $34 \mathrm{kDa}$ polyhedron envelope protein in Spodoptera frugiperda cells infected with Autographa californica nuclear polyhedrosis virus. Arch Virol 111:103-114

Vanderzant ES, Richardson CD, Fort SWJ (1962) Rearing of the bollworm on artificial diet. J Econ Entomol 55:140

Veenakumari K, Rabindra RJ, Srinivasa Naik CD et al (2006) Standardization of laboratory mass production of Amsacta albistriga nucleopolyhedrovirus. J Biol Control 20:183-190

Veenakumari K, Rabindra RJ, Srinivasa Naik CD, Shubha MR (2007) In situ field level mass production of Amsacta albistriga (Lepidoptera: Arctiidae) nucleopolyhedrovirus in a groundnut ecosystem in South India. Int J Trop Insect Sci 27:48-52

Vincent C, Andermatt M, Valéro J (2007) Madex ${ }^{\circledR}$ and VirosoftCP4 ${ }^{\circledR}$, viral biopesticides for coddling moth control. In: Vincent C, Goethel MS, Lazarovits G (eds) Biological control: a global perspective, Oxfordshire, UK, and Cambridge, USA: CAB International Virus taxonomy: seventh report of the international committee on taxonomy of viruses, pp 336-343

Vlak JM, Smith GE (1982) Orientation of the genome of Autographa californica nuclear polyhedrosis virus: a proposal. J Virol 41:1118-1121

Volkman LE, Falcon LA (1982) Use of monoclonal antibody in an enzyme-linked immunosorbent assay to detect the presence of Trichoplusia ni (Lepidoptera: Noctuidae) single nuclear polyhedrosis virus polyhedrin in T. ni larvae. J Econ Entomol 75:868-871

Volkman LE, Blissard GW, Friensen PD, Posse RD, Theilmann DA (1995) Baculovirudae. In: Murphy F, Fauquet CM, Bishop DHL, Jarvis AW, Martelly G, Mayo E, Summers M D (eds) Virus taxonomy: classification and nomenclature of viruses. Sixth report of the international committee on taxonomy of viruses. Arch Virol 10:104-113

Weiser J (1987) Patterns over place and time. In: Fuxa JR, Tanada Y (eds) Epizootiology of insect disease. Wiley, New York, pp 215-242

Wiegers F, Vlak JM (1984) Physical map of the DNA of a Mamestra brassicae nucleopolypolyhedrovirus variant isolates from Spodoptera exigua. J Gen Virol 65:2011-2019

Wigley PJ (1976) The epizootiology of a nuclear polyhedrosis virus disease of the winter moth, Operophtera burmata L. at Wistman's Wood, Dartmoor. D.Phil. Thesis, University of Oxford

William CF, Payne CC (1984) The susceptibility of Heliothis armigera (Hubner) larvae to three nuclear polyhedrosis viruses. Ann Appl Biol 104:405-412

Williams T (1993) Covert iridovirus infection in blackfly larvae. Proc Roy Soc Lond B 251:225230

Winstanley D, O’Reilly D (1999) Granuloviruses. In: Webster RG, Granoff A (eds) Encyclopedia of virology, 2nd edn. Academic, London, pp 69-84

Wolff JLC, Moraes RHP, Kitajima E, Leal EDS, Zanotto PMA (2002) Identification and characterization of a baculovirus from Lonomia obliqua (Lepidoptera: Saturniidae). J Invertebr Pathol 79:137-145

Wu C-Y, Wang C-H (2006) New cell lines from Lymantria xylina (Lepidoptera: Lymantriidae): characterization and susceptibility to baculoviruses. J Invertebr Pathol 93:186-191

Yendol WG, Hamlen RA (1973) Ecology of entomogenous viruses and fungi. Ann N Y Acad Sci 217:18-30

Zanotto PMD, Kessing BD, Maruniak JE (1993) Phylogenetic interrelationships among baculoviruses: evolutionary rates and host associations. J Invertebr Pathol 62:147-164

Zhang G, Kaupp WJ (1988) Use of monoclonal antibodies in an enzyme-linked immunosorbent assay to detect the Choristoneura fumiferana nuclear polyhedrosis virus. Chinese J Virol 4:6164 


\section{黛 Springer}

http://www.springer.com/978-3-319-14498-6

Biocontrol of Lepidopteran Pests

Use of Soil Microbes and their Metabolites

Sree, K.S.; Varma, A. (Eds.)

$2015, X, 344$ p. 66 illus., 11 illus. in color., Hardcover

ISBN: $978-3-319-14498-6$ 